Provided for non=commercial research and education use. Not for reproduction, distribution or commercial use.

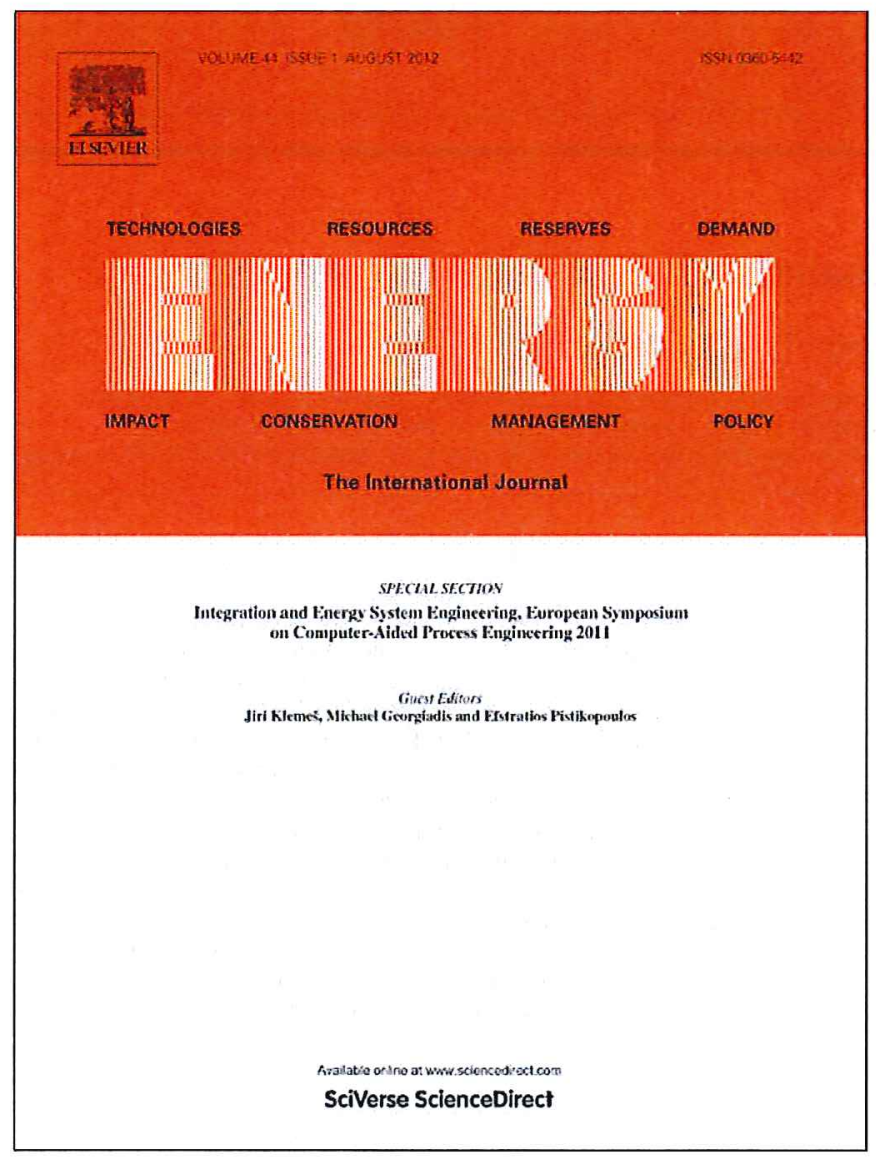

This article appeared in a journal published by Elsevier. The attached copy is furnished to the author for internal non-commercial research and education use, including for instruction at the authors institution and sharing with colleagues.

Other uses, including reproduction and distribution, or selling or licensing copies, or posting to personal, institutional or third party websites are prohibited.

In most cases authors are permitted to post their version of the article (e.g. in Word or Tex form) to their personal website or institutional repository. Authors requiring further information regarding Elsevier's archiving and manuscript policies are encouraged to visit:

http://www.elsevier.com/copyright 


\title{
Thermodynamic analysis of algal biocrude production
}

\author{
C.M. Beal ${ }^{\mathrm{a}, \mathrm{b}, *}$, R.E. Hebner ${ }^{\mathrm{a}, \mathrm{b}}$, M.E. Webber ${ }^{\mathrm{a}, \mathrm{c}}$ \\ ${ }^{a}$ Department of Mechanical Engineering, The University of Texas at Austin, 10100 Burnet Rd, EME 133, Austin, TX 78758, USA \\ ${ }^{\mathrm{b}}$ The Center for Electromechanics, The University of Texas at Austin, 10100 Burnet Rd, EME 133, Austin, TX 78758, USA \\ 'Center for International Energy and Environmental Policy, The University of Texas at Austin, 10100 Burnet Rd, EME 133, Austin, TX 78758, USA
}

\section{A R T I C L E I N F O}

\section{Article history:}

Received 13 August 2011

Received in revised form

15 March 2012

Accepted 1 May 2012

Available online 8 June 2012

\section{Keywords:}

Algal biofuel

Energy, entropy, and exergy

Thermodynamic efficiency

Energy return on investment

Exergy return on investment

Thermodynamics

\begin{abstract}
A B S T R A C T
Although algal biofuels possess great potential, profitable production is quite challenging. Much of this challenge is rooted in the thermodynamic constraints associated with producing fuels with high energy, low entropy, and high exergy from dispersed materials. In this study, a preliminary thermodynamic analysis is presented that calculates the energy, entropy, and exergy of the intermediate products for algal biocrude production. These values are also used in an initial attempt to characterize the thermodynamic efficiency of that system. The production pathway is simplified by assuming ideal solutions throughout. Results for the energy and exergy efficiencies, and the first-order energy and exergy return on investment, of the system are given.

The summary finding is that the first-order energy return on investment in the best case considered could be as high as 520, as compared to $1.7 \times 10^{-3}$ in the experimental unit under development. While this analysis shows that significant improvement may be possible, the ultimate thermodynamic efficiency of algal biofuels likely lies closer to the moderate case examined here, which yielded a first-order energy return on investment of 10 . For perspective, the first-order energy return on investment for oil and gas production has been estimated in the literature to be $\sim 35$.
\end{abstract}

(ㄷ) 2012 Elsevier Ltd. All rights reserved.

\section{Background}

Thermodynamic analyses are useful for determining the fundamental limits of system performance, particularly for assessing maximum performance levels. This research focuses on determining the maximum theoretical thermodynamic efficiency of an algal biocrude production system for comparison with the performance of real systems. Thus, the goal of this analysis is to determine the minimum amount of work input required for operating the biofuel production pathway analytically and compare that to the useful energy output of the system. Algal biofuel production is a developing industry, currently lacking established processes that lead to energy efficient and cost efficient fuel production [1-4]. Furthermore, there is little hard data for end-to-end production at large-scale. Consequently, in this environment, it is important to focus not only on incremental improvements in existing systems, but also on the fundamental limits to success.

\footnotetext{
* Corresponding author. Department of Mechanical Engineering, The University of Texas at Austin, 10100 Burnet Rd, EME 133, Austin, TX 78758, USA. Tel.: +1 540 230 5049; fax: +1 5124717700 .

E-mail addresses: colinmbeal@gmail.com, cbeal@mail.utexas.edu (C.M. Beal), r.hebner@cem.utexas.edu (R.E. Hebner), webber@mail.utexas.edu (M.E. Webber).
}

To assess those upper limits, this work focuses on a firstprinciples energy, entropy, and exergy analysis of the algal biocrude production system shown in Fig. 1. The thermodynamic properties for the intermediate products in this production system are calculated and these values are used in an initial attempt to characterize the fundamental thermodynamic efficiencies of the system. As the algal biofuel production process is carried out, the intermediate products increase in energy density and decrease in specific entropy. The necessity to traverse "down" the entropy ladder, with entropy decreasing and energy density increasing throughout the production pathway, is fundamental to all phototrophic biofuel production.

With knowledge of the energy and entropy of a system (or substance), one can determine the exergy of that system, which is the maximum work that could be produced by that system during ideal processes through which the system is equilibrated with the environment. Therefore, the exergy of a system represents the upper bound of the maximum possible work potential.

In a biofuel production system, the specific exergy of the intermediate products increases throughout the production pathway. This effect is correlated to the decreasing entropy of the intermediate products throughout the production pathway as illustrated in Equation (1), 


\begin{tabular}{|c|c|c|c|}
\hline \multicolumn{2}{|c|}{ Abbreviations } & BT & $\begin{array}{l}\text { total exergy flow in units of joules per square meter of } \\
\text { growth volume per day }\end{array}$ \\
\hline \multicolumn{2}{|c|}{ General nomenclature } & B́T & $\begin{array}{l}\text { total exergy flow in units of joules per liter of processed } \\
\text { volume }\end{array}$ \\
\hline$B$ & exergy in units of joules per square meter of growth & $\mathrm{PE}$ & photosynthetic efficiency (dimensionless) \\
\hline$\dot{B}$ & $\begin{array}{l}\text { volume per day } \\
\text { exergy in units of joules per liter of processed volume }\end{array}$ & PAR & photosynthetically active radiation percentage \\
\hline$b$ & exergy in units of joules per mole & PTE & photon transmission efficiency (dimensionless) \\
\hline$E$ & energy (nonspecific units) & PUE & photon utilization efficiency (dimensionless) \\
\hline$P$ & pressure (nonspecific units) & $\alpha$ & photon-to-glucose conversion efficiency \\
\hline$\forall$ & volume (nonspecific units) & & (dimensionless) \\
\hline$T$ & temperature in units of Kelvin & CoL & cost of living (dimensionless) \\
\hline$S$ & $\begin{array}{l}\text { entropy in units of joules per square meter of growth } \\
\text { volume per day per degree } \mathrm{K}\end{array}$ & $\tau$ & $\begin{array}{l}\text { glucose-to-biomass conversion efficiency } \\
\text { (dimensionless) }\end{array}$ \\
\hline$\dot{S}$ & $\begin{array}{l}\text { entropy in units of joules per liter of processed volume } \\
\text { per degree } \mathrm{K}\end{array}$ & $\beta$ & $\begin{array}{l}\text { unnamed parameter characterizing the conversion of } \\
\text { PAR radiation to biomass (dimensionless) }\end{array}$ \\
\hline$s$ & entropy in units of joules per mol per degree $\mathrm{K}$ & $Q$ & heat in units of joules per square meter of growth \\
\hline$d$ & pond depth in units of meters & & volume per day \\
\hline$t_{c}$ & cultivation time in units of days & $\dot{Q}$ & heat in units of joules per liter of processed volume. \\
\hline$n$ & amount of substance in units of moles & EROI & energy return on investment (dimensionless) \\
\hline n & amount of substance in units of moles per liter & BROI & exergy return on investment (dimensionless) \\
\hline$R$ & universal gas constant $(8.314 \mathrm{~J} / \mathrm{mol}-\mathrm{K})$ & Products & \\
\hline HHV & $\begin{array}{l}\text { mole fraction (dimensionless) } \\
\text { higher heating value in units of megajoules per }\end{array}$ & $\begin{array}{l}\text { Products } \\
\text { GV }\end{array}$ & oroweth yolume \\
\hline & $\begin{array}{l}\text { kilogram } \\
\text { lites }\end{array}$ & $A C$ & algal concentrate \\
\hline W & work in units of joules per square meter of growth & DW & discharge water \\
\hline & volume per day & LC & lysed concentrate \\
\hline$\dot{W}$ & work in units of joules per liter of processed volume & TAG & triacylglycerol \\
\hline$\varphi$ & processing efficiency (dimensionless) & LL & lysing loss \\
\hline$\eta$ & thermodynamic efficiency (dimensionless) & $\mathrm{BC}$ & biocrude \\
\hline$E D$ & direct energy flow in units of joules per square meter of & LM & lysed mass \\
\hline ÉD & growth volume per day & BL & biocrude loss \\
\hline$E D$ & $\begin{array}{l}\text { direct energy flow in units of joules per liter of } \\
\text { processed volume }\end{array}$ & BS & biomass in slurry \\
\hline ET & total energy flow in units of joules per square meter of & $\begin{array}{l}\text { BSL } \\
\text { GM }\end{array}$ & $\begin{array}{l}\text { biomass in slurry loss } \\
\text { grown mass }\end{array}$ \\
\hline & growth volume per day & HM & harvested mass \\
\hline ÉT & $\begin{array}{l}\text { total energy flow in units of joules per liter of } \\
\text { processed volume }\end{array}$ & Bо & bio-oil \\
\hline$B D$ & $\begin{array}{l}\text { direct exergy flow in units of joules per square meter of } \\
\text { growth volume per day }\end{array}$ & $\begin{array}{l}\text { Processes } \\
\text { growth }\end{array}$ & growth \\
\hline$B D$ & $\begin{array}{l}\text { direct exergy flow in units of joules per liter of } \\
\text { processed volume }\end{array}$ & $\begin{array}{l}\text { harv } \\
\text { cellys } \\
\text { sep }\end{array}$ & $\begin{array}{l}\text { harvesting } \\
\text { cell lysing } \\
\text { separations }\end{array}$ \\
\hline
\end{tabular}

$\Delta B=\Delta E+P_{0} \Delta \forall-T_{0} \Delta S$

where $\Delta B$ is the change in exergy (during a processing step, for instance), $\Delta E$ is the change in exergy due to a change in internal energy (with $\Delta E=\Delta\left(U+1 / 2 V^{2}+g z\right.$ ), which is the change in energy from internal energy, $U$, kinetic energy, $1 / 2 V^{2}$, and gravitational potential energy, $g z), P_{o} \Delta \forall$ is the change in exergy due to a change in volume, and $T_{0} \Delta S$ is the change in exergy associated with a change in entropy. For the algal biofuel production pathway (neglecting kinetic energy, gravitational potential energy, and work from changes in volume), this equation reduces to,

$\Delta B=\Delta U-T_{o} \Delta S$

Therefore, if the internal energy of a system (or substance) is unchanged during a processing step $(\Delta U=0)$, exergy is increased $(\Delta B>0)$ when entropy is decreased $(\Delta S<0)$. As stipulated by the second law of thermodynamics, the entropy of a closed system can be decreased by extracting heat from, or performing work on, the system. The algal biofuel production pathway is generally in thermal equilibrium with the dead-state environment, which leaves performing work on the system as the only way to reduce the entropy and increase the exergy of the intermediate products. The fundamental questions thereby become

1) What is the minimum amount of work (i.e., energy) required to produce fuel from algae?

2) How does this theoretical minimum work input compare to the amount of energy (i.e., work) produced from the system?

Knowledge of the minimum work input required would provide insight into the maximum possible thermodynamic efficiencies of algal biofuel production and provide metrics by which real production processes could be judged (analogous to calculating the efficiency of an engine or generator). This study aims to provide an initial answer to these questions as a contribution to better understanding the potential of algal biofuel. 


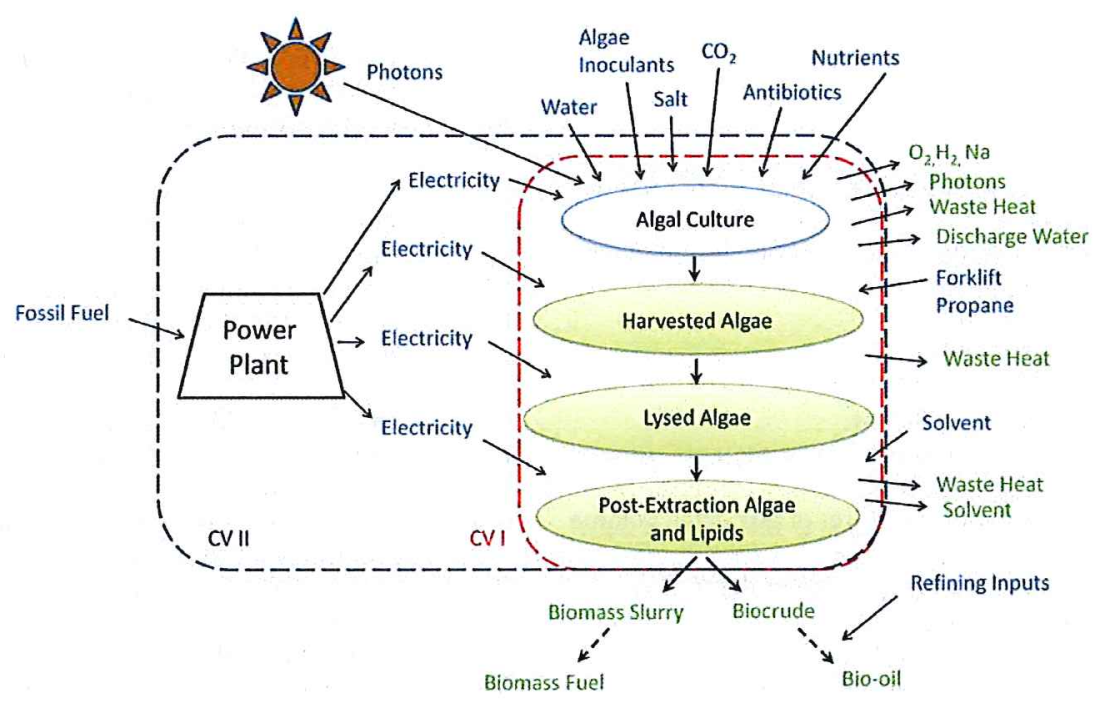

Fig. 1. Algal biofuel production process. Control volume II (CV II) includes an electric power plant in addition to the algal biofuel processing steps in control volume I (CV I). Some of the materials required for operating an actual process (e.g., inoculants, antibiotics, and solvent) are neglected in this first-principles analysis.

The energy, entropy, and exergy flows are defined for three scenarios: 1) the Experimental Case (EC), which has been described in previous publications $[1,5], 2)$ the Highly Productive Case II (HPCII), which is similar to the Highly Productive Case that is presented in $[1,5]$, and 3 ) the Idealized Case (IC), ${ }^{1}$ which assumes ideal growth and processing. The key measurements for the Experimental Case and assumptions for the other cases are shown in Table 1.

Energy analyses have been conducted previously for algal cultivation [6-8] and an exergy analysis of rapeseed, soybean, and corn biofuels has been presented [9]. In addition, Sorguven and Ozilgen estimated the cumulative net exergy consumption for algal biodiesel production based on a specific model process [10]. While that study presents a useful exergy analysis (particularly associated with the transesterification reaction, which is also addressed by [11]), it is based on specific growth, harvesting, and oil extraction processes that have not been validated in practice, and do not relate to the fundamental thermodynamic constraints on algal biofuel production (which is the goal of the present study). The hypothetical case presented by Sorguven and Ozilgen and the Experimental Case presented here serve as useful references to the analytical first-principles results of the present study. Finally, Kucukvar and Tatari presented a life-cycle-analysis for co-firing algal biomass with coal for electricity generation, and consider industrial and ecological exergy [12]. However, to the best of our knowledge, this is the first study to conduct an end-to-end firstprinciples thermodynamic assessment of an algal biofuel production process by including the following evaluations: a detailed energy and exergy balance for growth; calculating the energy, entropy, and exergy of all intermediate products; and presenting the energetic efficiency, exergetic efficiency, energy return on investment (EROI), and exergy return on investment (BROI) for the overall process.

\footnotetext{
${ }^{1}$ The Idealized Case presented here is the same as the Theoretical Optimum Case presented previously by the authors in [5] Beal C.M. Constraints on Algal Biofuel Production. Austin TX, http://repositories.lib.utexas.edu/handle/2152/ETD-UT-201105-2775: Doctoral Dissertation, University of Texas at Austin, 2011.
}

\subsection{Fundamental assumptions}

This basic analysis makes some simplifying assumptions to focus on describing the fundamental behavior without addressing the complexity of each individual step in the process. The following important assumptions were made:

- The calculations assume that each intermediate product is an ideal solution of two or three parts. In an ideal solution, the interactions among molecules are negligible, such as in an ideal gas $[13,14]$. This assumption simplifies the analysis greatly, but also neglects interactions associated with the constituents of

Table 1

Key measurements and assumptions for the Experimental Case (EC), Highly Productive Case II (HPCII), and Idealized Case (IC). A liter of processed growth volume is reported as $\mathbf{L}_{\mathbf{p}}$ (see Units and process description below).

\begin{tabular}{|c|c|c|c|}
\hline & EC & HPCII & IC \\
\hline $\begin{array}{l}\text { Photosynthetic } \\
\text { efficiency (\%) }\end{array}$ & NA & 5.6 & 11.9 \\
\hline Water loss & $1.91 \mathrm{~L} / \mathrm{L}_{\mathrm{p}}$ & $\begin{array}{l}\text { None (closed } \\
\text { system) }\end{array}$ & $\begin{array}{l}\text { None (closed } \\
\text { system) }\end{array}$ \\
\hline Nutrient uptake & Poor & Optimistic & Ideal maximum \\
\hline Carbon Dioxide & $36 \mathrm{~g} \mathrm{CO}_{2} / \mathrm{g}$ algae & $8 \mathrm{~g} \mathrm{CO}_{2} / \mathrm{g}$ algae & $1.9 \mathrm{~g} \mathrm{CO}_{2} / \mathrm{g}$ algae \\
\hline Nitrogen & $769 \mathrm{mg} \mathrm{N} / \mathrm{g}$ algae & $70 \mathrm{mg} \mathrm{N} / \mathrm{g}$ algae & $70 \mathrm{mg}$ N/g algae \\
\hline Phosphorus & $12 \mathrm{mg} P / g$ algae & $8 \mathrm{mg} \mathrm{P} / \mathrm{g}$ algae & $8 \mathrm{mg} \mathrm{P} / \mathrm{g}$ algae \\
\hline $\begin{array}{l}\text { Electricity use for } \\
\text { growth }\end{array}$ & $19,000 \mathrm{~J} / \mathrm{L}-d$ & $99 \mathrm{~J} / \mathrm{L}-\mathrm{d}$ & None \\
\hline Cultivation time & $123 d$ & $8.2 \mathrm{~d}$ & $5.4 \mathrm{~d}$ \\
\hline $\begin{array}{l}\text { Algal concentration } \\
\text { at harvesting }\end{array}$ & $0.26 \mathrm{~g} / \mathrm{L}$ & $1 \mathrm{~g} / \mathrm{L}$ & $5 \mathrm{~g} / \mathrm{L}$ \\
\hline Lipid Fraction & 0.02 & 0.5 & 0.5 \\
\hline Concentration method & Centrifuge & Natural settling & Ideal \\
\hline Harvesting efficiency & $92 \%$ & $95 \%$ & $100 \%$ \\
\hline Harvesting energy & $23 \mathrm{~kJ} / \mathrm{L}_{\mathrm{p}}$ & $1 \mathrm{~kJ} / \mathrm{L}_{\mathrm{p}}$ & $0.02 \mathrm{~kJ} / \mathrm{L}_{\mathrm{p}}$ \\
\hline Lysing method & Electrical & Electrical & Electrical \\
\hline Lysing efficiency & $92 \%$ & $99 \%$ & $100 \%$ \\
\hline Lysing energy & $3.8 \mathrm{~kJ} / \mathrm{L}_{\mathrm{p}}$ & $0.21 \mathrm{~kJ} / \mathrm{L}_{\mathrm{p}}$ & $0 \mathrm{~kJ} / \mathrm{L}_{\mathrm{p}}$ \\
\hline Separation method & Membrane & Ideal & Ideal \\
\hline Lipid recovery ${ }^{a}$ & $90 \%$ & $90 \%$ & $100 \%$ \\
\hline Separation energy & $24 \mathrm{~kJ} / \mathrm{L}_{\mathrm{p}}$ & $0.19 \mathrm{~kJ} / \mathrm{L}_{\mathrm{p}}$ & $0.21 \mathrm{~kJ} / \mathrm{L}_{\mathrm{p}}$ \\
\hline
\end{tabular}

${ }^{a}$ The separations efficiency combines the lipid fraction and the lipid recovery percentage. 
algae (which are compartmentalized in a complex organization of compounds) and the interactions among algal cells and their surroundings.

- The process considered is heliotropic growth followed by harvesting, lysing, and bio-oil separations. The analysis approach is expected to be valid for other processes, but the values associated with each step may differ.

- The dead-state equilibrium (i.e., the environment) is defined according to Szargut et al. as the earth's atmosphere [15] and standard conditions are assumed throughout.

- Several practical necessities, such as pumping between production steps and solvents required for separations, are also omitted; although, these items can be major components of the energetic cost of algal biofuel production in real systems (cf. $[1,5]$ ). They are omitted because the details are process specific and likely location specific. Their omission should not be interpreted as an indicator that they are insignificant.

- The impact of scattering by water in the growth volume is not considered explicitly and the exergy-to-energy ratio of incident radiation is assumed to be $0.93[15,16]$.

\section{Energy, entropy, and exergy of each processing step}

\subsection{Methodology}

A first-law analysis is presented that accounts for all energy inputs to the system and allocates the conversion of these energy inputs into chemical and thermal energy flows. In this analysis, it is assumed that the system is operating in steady-state, and thus, it has already been created (construction energy (i.e., capital) is neglected). In addition, the specific and total exergies are calculated for each intermediate product (i.e., the growth volume, algal concentrate, discharge water, lysed algal concentrate, biocrude, and post-extraction algal biomass slurry).

\subsection{Units and process description}

The nomenclature and terminology have been adopted from $[17,18]$. The energy content of solar radiation is typically reported as an aerial power input that can be represented with units of megajoules per meter squared per year $\left(\mathrm{MJ} / \mathrm{m}^{2}-\mathrm{yr}\right)$. The energy and exergy data associated with the growth phase are also reported in units of $\mathrm{MJ} / \mathrm{m}^{2}$-yr. For each of the three cases, any value in these units can be converted to volumetric units of megajoules per liter of growth volume processed $\left(\mathrm{MJ} / \mathrm{L}_{\mathrm{p}}\right)$ according to,

$$
\left[\frac{\mathrm{MJ}}{\mathrm{m}^{2}-\mathrm{yr}}\right] \cdot\left[\frac{1 \mathrm{yr}}{365 \mathrm{day}}\right] \cdot \frac{1}{d[\mathrm{~m}]} \cdot\left[\frac{\mathrm{m}^{3}}{1000 \mathrm{~L}}\right] \cdot t_{c}[\mathrm{day}] \equiv\left[\frac{\mathrm{M} J}{\mathrm{~L}_{\mathrm{p}}}\right]
$$

where $d$ is pond depth ( $0.2 \mathrm{~m}$ for all cases) and $t_{c}$ is cultivation time (123 days, 8.17 days, and 5.43 days, for the Experimental, Highly Productive II, and Idealized Cases, respectively). These cultivation times were calculated by dividing the assumed algal concentration at the time of harvesting (in $\mathrm{g} / \mathrm{L}$ ) by the biomass productivity (in $\mathrm{g} /$ $\mathrm{L}-d$ ) that is derived from the growth model. The entropy data can be converted similarly, as,

$\left[\frac{\mathrm{MJ}}{\mathrm{m}^{2}-\mathrm{yr}-\mathrm{K}}\right] \cdot\left[\frac{1 \mathrm{yr}}{365 \mathrm{day}}\right] \cdot \frac{1}{d[\mathrm{~m}]} \cdot\left[\frac{\mathrm{m}^{3}}{1000 \mathrm{~L}}\right] \cdot t_{c}[\mathrm{day}] \equiv\left[\frac{\mathrm{MJ}}{\mathrm{L}_{\mathrm{p}}-\mathrm{K}}\right]$

To track energy, entropy, and exergy throughout the system using a single reference metric, data are reported not only with respect to the volume of each intermediate product (e.g., the exergy content per liter of algal concentrate $\left.(\mathrm{J} / \mathrm{L}), B_{\mathrm{AC}}\right)$, but also with respect to the total growth volume processed (e.g., the exergy content of algal concentrate per liter of processed volume $\left(\mathrm{J} / \mathrm{L}_{\mathrm{p}}\right)$, $\left.\dot{B}_{A C}\right)$. To distinguish between these units, the notation $L$ and $L_{p}$ are used, respectively. Additionally, data presented with respect to the growth volume processed are denoted with an apostrophe accent, such as $B_{\mathrm{AC}}$.

\subsection{Growth}

\subsubsection{Growth energy balance}

The energy balance for the growth volume is presented in Appendix $A$, and the analysis simplifies the photosynthesis and metabolism processes in an algal culture to enable direct, simple calculations. The analysis is based on the framework presented by Weyer et al. [8], who outline the critical energy conversion steps for photosynthetic algal growth, and uses algae stoichiometry estimates presented by Clarens et al. [19]. Specific data for each input of the three cases are shown in Fig. 2 with respect to $6500 \mathrm{MJ} / \mathrm{m}^{2}-\mathrm{yr}$ for the Experimental and Highly Productive Cases and $11,616 \mathrm{MJ} / \mathrm{m}^{2}$ yr for the Idealized Case. Lundquist et al. and Robertson et al. presented similar analyses [6,7]. For the growth phase, the energy balance for the Highly Productive Case II and the Idealized Case is balanced to within $0.5 \%$, as shown in Fig. 2 and described in Appendix A. The photosynthetic efficiency (PE) of each case is also presented in Appendix A, yielding values of $5.6 \%$ and $11.9 \%$ for the Highly Productive Case II and the Idealized Case, respectively. The PE of the Highly Productive Case II is reasonable when compared to experimentally proven rates for algal cultivation and the Idealized Case result corresponds to the maximum theoretical photosynthetic efficiency [20].

\subsubsection{Entropy of the growth volume}

The entropy of several of the input and output flows for algal cultivation is shown in Fig. 2. Additionally, Table C-1 lists the growth volume composition and the entropy of the growth volume for the Experimental Case, Highly Productive Case II, and Idealized Case, which are $3.88 \mathrm{~kJ} / \mathrm{L}-\mathrm{K}, 3.88 \mathrm{~kJ} / \mathrm{L}-\mathrm{K}$, and $3.87 \mathrm{~kJ} / \mathrm{L}-\mathrm{K}$, respectively. The specific entropy of an ideal solution at standard conditions, $\hat{S}^{\circ}$, is calculated as,

$\hat{S}^{\circ}=\sum \hat{n}_{i} \cdot \tilde{S}_{i}^{\circ} \quad\left[\frac{\mathrm{kJ}}{\mathrm{L}-\mathrm{K}}\right]$

where $\dot{n}_{i}$ is the specific molar concentration of component $i$ (in mol/L) and $\tilde{s}_{i}^{\circ}$ is the standard partial molar entropy of component $i$ (in $\mathrm{kJ} / \mathrm{mol}-\mathrm{K}$ ). The standard partial molar entropy of each component can be calculated according to,

$\tilde{s}_{i}^{\circ}=s_{i}^{\circ}-R \ln \left(y_{i}\right) \quad\left[\frac{\mathrm{J}}{\mathrm{mol}-\mathrm{K}}\right]$

where $s^{\circ}$ is the total molar entropy, $R$ is the gas constant $(8.314 \mathrm{~J} /$ mol-K), and $y$ is the mole fraction of the component [13]. Based on the empirical correlations provided by Battley, the entropy of algal biomass with a molecular weight of $2414 \mathrm{~g} / \mathrm{mol}$ is approximately $3180 \mathrm{~J} / \mathrm{mol}-\mathrm{K}$ [21]. This value agrees within $25 \%$ of the result obtained using the approximation presented by Ikumi et al. for calculating the entropy of coal (which has a similar composition of carbon, hydrogen, oxygen, and nitrogen) [22], which is $3937 \mathrm{~J} / \mathrm{mol}-\mathrm{K}$. The entropy of water is $69.92 \mathrm{~J} / \mathrm{mol}-\mathrm{K}$ [13].

\subsubsection{Exergy of the growth volume}

Fig. 2 lists the exergy of each energy and material input to the growth volume. The exergy of solar radiation has received extensive attention in the literature $[9,15,16,23-26]$ and many studies assume an exergy-to-energy ratio of $0.93[9,15]$, which corresponds 


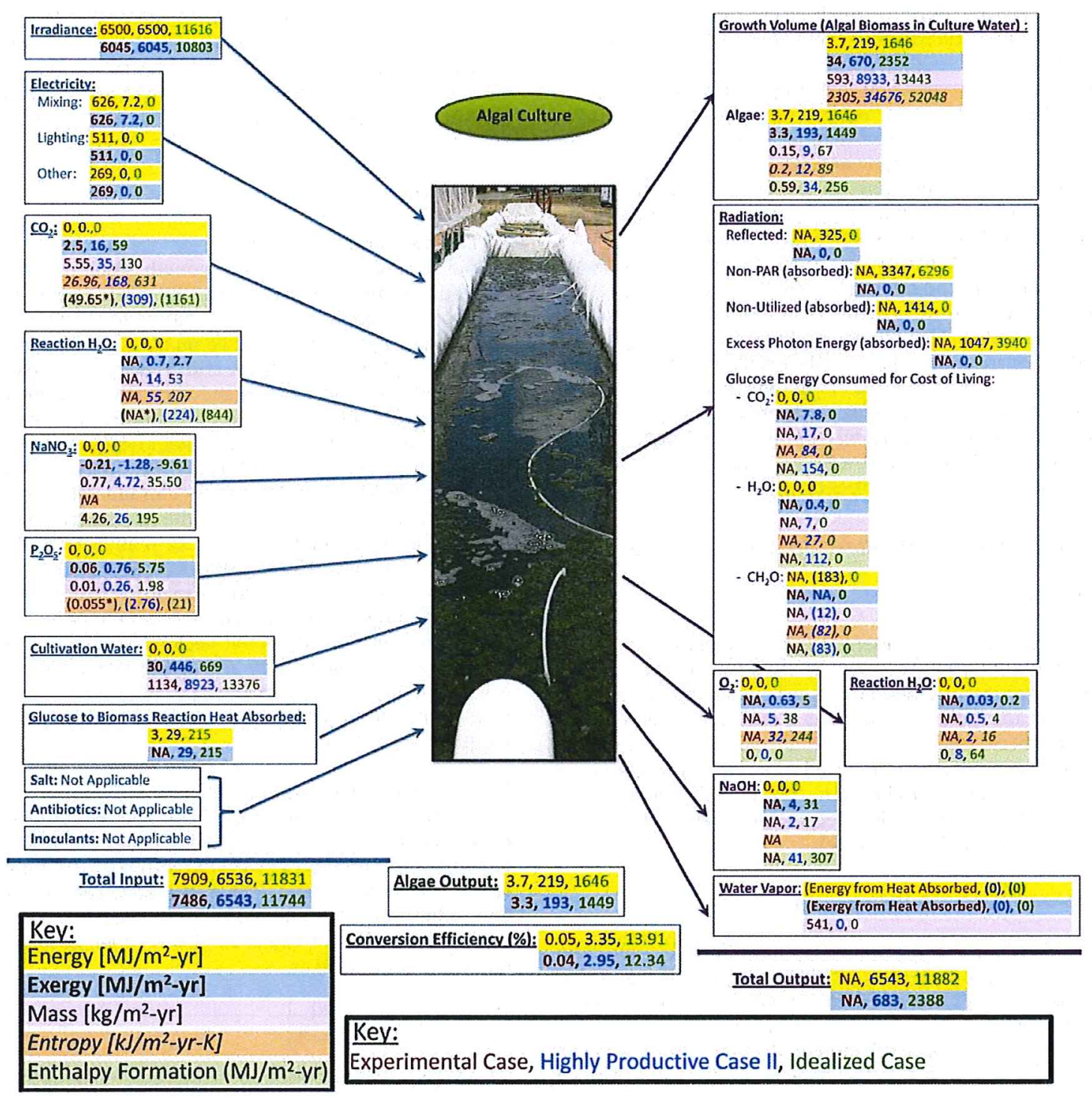

Fig. 2. Energy, entropy, and exergy flows associated with growth.

to direct solar radiation absorbed by a black-body $[15,16]$. The difference between exergy and energy is associated with emission and absorption effects of the solar conversion system. In real algal cultivation systems, scattering by water will reduce the available energy and exergy of incident sunlight once it has entered the growth volume [16]. The specific scattering interactions are beyond the scope of this study and the associated losses are not considered explicitly in the present analysis. However, in this model, these losses are considered implicitly because the non-PAR radiation is absorbed by the growth volume and much of the PAR radiation is also absorbed by the growth volume, as specified by the photonutilization efficiency (PUE). Appendix A provides a detailed discussion of the energy and exergy balances for growth.

The exergy for electrical energy inputs was assumed to be equal to the energy input and the exergies for material inputs were determined using the standard chemical exergy values $\left(b_{c h}^{\circ}\right)$ listed in reference materials: $19,870 \mathrm{~J} / \mathrm{mol}$ for $\mathrm{CO}_{2}, 900 \mathrm{~J} / \mathrm{mol}$ for $\mathrm{H}_{2} \mathrm{O}(l)$,
$9500 \mathrm{~J} / \mathrm{mol}$ for $\mathrm{H}_{2} \mathrm{O}(\mathrm{g}),-22,700 \mathrm{~J} / \mathrm{mol}$ for $\mathrm{NaNO}_{3}, 412,650 \mathrm{~J} / \mathrm{mol}$ for $\mathrm{P}_{2} \mathrm{O}_{5}, 3970 \mathrm{~J} / \mathrm{mol}$ for $\mathrm{O}_{2}$, and $74,900 \mathrm{~J} / \mathrm{mol}$ for $\mathrm{NaOH}[15,27]$. As shown in Fig. 2, the conversion efficiency of solar exergy to biomass exergy is $0.04 \%, 3 \%$, and $12 \%$ for the Experimental Case, Highly Productive Case II, and Idealized Case.

The specific exergy of the growth volume, $\dot{B}_{G V}$, was determined assuming an ideal solution from Equation (7), which is,

$$
\dot{B}=\sum \tilde{n}_{i} \cdot \tilde{b}_{c h_{i}}^{\circ} \quad\left[\frac{\mathrm{J}}{\mathrm{kL}}\right]
$$

where $\dot{n}_{i}$ is the specific molar concentration of component $i$ (in mol/ $\mathrm{kL})$ and $\tilde{b}_{c h_{\mathrm{i}}}$ is the specific molar chemical exergy of each component, which can be calculated according to,

$\tilde{b}_{c h_{i}}^{\circ}=b_{c h_{i}}^{\circ}+R T_{0} \ln \left(y_{i}\right) \quad\left[\frac{\mathrm{J}}{\mathrm{mol}}\right]$ 
where $b_{c h_{i}}^{\circ}$ is the standard chemical exergy of component $i$ and $T_{0}$ is the environment temperature $(298 \mathrm{~K})$. The standard chemical exergy of the algal biomass, $b_{c h}^{\circ}$, can be calculated using Equation (A-10) (cf. Appendix A) as described by Szargut et al. [15] and Moran and Shapiro [27] to be,

$$
\begin{aligned}
b_{c h_{\text {algae }}}^{\circ}= & \mathrm{HHV}-T_{0}\left[s_{\text {algae }}+n_{\mathrm{O}_{2}} \cdot s_{\mathrm{O}_{2}}-n_{\mathrm{CO}_{2}} \cdot s_{\mathrm{CO}_{2}}-n_{\mathrm{H}_{2} \mathrm{O}} \cdot s_{\mathrm{H}_{2} \mathrm{O}}\right. \\
& \left.-n_{\mathrm{N}_{2}} \cdot s_{\mathrm{N}_{2}}-n_{\mathrm{P}_{2} \mathrm{O}_{5}} \cdot s_{\mathrm{P}_{2} \mathrm{O}_{5}}\right]+n_{\mathrm{CO}_{2}} \cdot b_{\mathrm{CO}_{2}}+n_{\mathrm{H}_{2} \mathrm{O}} \cdot b_{\mathrm{H}_{2} \mathrm{O}} \\
& +n_{\mathrm{N}_{2}} \cdot b_{\mathrm{N}_{2}}+n_{\mathrm{P}_{2} \mathrm{O}_{5}} \cdot b_{\mathrm{P}_{2} \mathrm{O}_{5}}-n_{\mathrm{O}_{2}} \cdot b_{\mathrm{O}_{2}}
\end{aligned}
$$

where HHV is the higher heating value of algal biomass, $s$ is the entropy of each compound, and $n$ is the amount of each compound in Equation (A-10). At standard conditions, with a HHV of $59.12 \mathrm{MJ} /$ $\mathrm{mol}(24.49 \mathrm{MJ} / \mathrm{kg}$, cf. Appendix A), the entropy of algae being $3180 \mathrm{~J} /$ mol-K, standard chemical exergies listed above, and standard entropy values for each component as listed in reference materials $[15,27]$, the standard chemical exergy for algae is $60.48 \mathrm{MJ} / \mathrm{mol}$ $(25.05 \mathrm{MJ} / \mathrm{kg}$ ). This value is within $2 \%$ of an independent estimate for the chemical exergy of algae based on the approximate method presented by Lu et al. [28], which is calculated as 1.11 times the lower heating value $(22.84 \mathrm{MJ} / \mathrm{kg}$, cf. Appendix A), yielding a chemical exergy of $25.35 \mathrm{MJ} / \mathrm{kg}$. Using the relations in Equations (7) and (8), the exergy of the growth volume for the Experimental Case, Highly Productive Case II, and Idealized Case is $56.50 \mathrm{MJ} / \mathrm{kL}$ $74.99 \mathrm{MJ} / \mathrm{kL}$, and $174.96 \mathrm{MJ} / \mathrm{kL}$, respectively, as listed in Table $\mathrm{C}-1$.

The exergy balance for cultivation is,

$\dot{B}_{\mathrm{GV}}=\dot{B}_{\mathrm{in}}+\dot{W}_{\mathrm{in}}-T_{0} \dot{S}_{\mathrm{gen}}$

where $B_{G V}$ is the exergy per liter of the growth volume (GV) processed, $\hat{B}_{\text {in }}$ is the total (non-work) exergy input from solar radiation and material exergy inputs per L processed, $W_{\text {in }}$ is the work input per $\mathbf{L}$ processed, and $\dot{S}_{\text {gen }}$ is the entropy generation per liter of processed volume. Setting the entropy generation term in Equation (10) equal to zero (assuming a reversible process) and inserting exergy data listed in Table 2 and Table $\mathrm{C}-1$ yields the minimum work input required for each case. Because there is an excess of exergy supplied to the system, the minimum work input required for growth is zero for all three cases.

\begin{tabular}{|c|c|c|c|}
\hline & EC & HPCII & IC \\
\hline \multicolumn{4}{|l|}{ Growth } \\
\hline Total energy input to growth (MJ/m² $-\mathrm{yr})$ & 7909.00 & 6536.00 & $11,831.00$ \\
\hline Photosynthetic efficiency (\%) & NA & 5.64 & 11.88 \\
\hline Total energy output from growth ( $\mathrm{MJ} / \mathrm{m}^{2}$-yr) & NA & 6543.00 & $11,882.00$ \\
\hline Total exergy input to growth $\left(\mathrm{MJ} / \mathrm{m}^{2}-\mathrm{yr}\right)$ & 7486.16 & 6542.78 & $11,744.17$ \\
\hline Total exergy output from growth (MJ/m² $-\mathrm{yr})$ & NA & 7009.76 & $12,635.97$ \\
\hline Growth volume exergy $\left(\mathrm{MJ} / \mathrm{m}^{2}-\mathrm{yr}\right)$ & 33.53 & 669.86 & 2351.91 \\
\hline \multicolumn{4}{|l|}{ Growth volume } \\
\hline Algal concentration $(\mathrm{g} / \mathrm{L})$ & 0.26 & 1.00 & 5.00 \\
\hline Grown mass productivity $\left(\mathrm{g} / \mathrm{m}^{2}-\mathrm{d}\right)$ & 0.43 & 24.50 & 184.00 \\
\hline Energy content per $\mathrm{m}^{2}-\mathrm{yr}\left(\mathrm{MJ} / \mathrm{m}^{2}-\mathrm{yr}\right)$ & 3.78 & 218.78 & 1646.23 \\
\hline Energy content per $\mathrm{kL}$ processed $\left(\mathrm{MJ} / \mathrm{kL}_{\mathrm{p}}\right)$ & 6.37 & 24.49 & 122.45 \\
\hline Entropy per $\mathrm{m}^{2}-\mathrm{yr}-\mathrm{K}\left(\mathrm{kJ} / \mathrm{m}^{2}-\mathrm{yr}-\mathrm{K}\right)$ & 2304.78 & $34,675.76$ & $52,047.75$ \\
\hline Entropy per $\mathrm{L}$ processed $\left(\mathrm{kJ} / \mathrm{L}_{\mathrm{p}}-\mathrm{K}\right)$ & 3.88 & 3.88 & 3.87 \\
\hline Exergy per $\mathrm{m}^{2}-\mathrm{yr}\left(\mathrm{MJ} / \mathrm{m}^{2}-\mathrm{yr}\right)$ & 33.53 & 669.86 & 2351.91 \\
\hline Exergy per kL processed (MJ/kL $)$ & 56.50 & 74.99 & 174.96 \\
\hline Minimum work input needed $\left(\mathrm{kJ} / \mathrm{L}_{\mathrm{p}}\right)$ & NA & 0.00 & 0.00 \\
\hline Work input $\left(\mathrm{kJ} / \mathrm{L}_{\mathrm{p}}\right)$ & 2475.45 & 0.81 & 0.00 \\
\hline Total entropy generation $\left(\mathrm{MJ} / \mathrm{m}^{2}-\mathrm{yr}-\mathrm{K}\right)$ & 25.01 & 19.71 & 31.52 \\
\hline Total entropy generation $\left(\mathrm{kJ} / \mathrm{L}_{\mathrm{p}}-\mathrm{K}\right)$ & 42.14 & 2.21 & 2.34 \\
\hline
\end{tabular}

Table 2

Energy, entropy, and exergy summary of growth.
For real processes, the amount of entropy generation can be determined by solving Equation (10) using the actual work that was performed on the system, as listed in Table 2. In the Highly Productive Case II, the only work input is from mixing and the Idealized Case assumes no work inputs. For each case, reflection and absorption of irradiance (with subsequent dissipation to the environment) results in a large amount of exergy loss and entropy generation, as illustrated in Fig. 4 and Appendix A.

\subsubsection{Additional parameters for growth}

The cultivation process model is greatly simplified with respect to real conditions for growing algae. Specifically, energy required to supply nutrients (including $\mathrm{CO}_{2}$ ) is neglected and mixing is assumed to be accomplished at no cost in the Idealized Case and at a minimal cost ( $99 \mathrm{~J} / \mathrm{L}-d)$ in the Highly Productive Case II. A more detailed radiation model is needed to determine the scattering losses from water in the growth volume and to calculate absorption characteristics for photosynthesis in algal cultures with similar detail as the analysis presented by Petela for plants [25]. In addition, more specific data are needed regarding nutrient uptake and mass transfer [29], as it was assumed that $100 \%$ of nitrogen and phosphorus are assimilated into biomass, and all other nutrients were neglected. The exergy impact of evaporation and the impact of additional materials in the culture media (e.g., salt) and contaminants should also be considered.

\subsection{Harvesting}

\subsubsection{Harvesting energy balance}

The harvesting process consists of one material input (the growth volume), two material outputs (algal concentrate and discharge water), work input, and heat dissipation output. Assuming the biomass energy content does not change during harvesting, the energy content of the algal concentrate (AC) (in kJ per $L$ of processed volume) is calculated as,

$E_{\mathrm{AC}}=\varphi_{\mathrm{harv}} \cdot \dot{E} D_{\mathrm{GV}} \quad\left[\frac{\mathrm{kJ}}{\mathrm{L}_{\mathrm{p}}}\right]$

where $\varphi_{\text {harv }}$ is the harvesting efficiency $(0.92,0.95$, and 1 for Experimental Case, Highly Productive Case II, and Idealized Case, respectively). To satisfy the first law, it is assumed that all work added to the system during harvesting is dissipated as heat. The energy content of the algal concentrate and discharge water are listed in Table 3.

\subsubsection{Entropy of the algal concentrate and discharge water}

As was done for the growth volume, the entropy of the algal concentrate and discharge water can be calculated from Equations (5) and (6) and the relevant data are listed in Tables C-2 and C-3. As one would expect, the algal concentrate has lower specific entropy than the growth volume, which reflects the greater difference between the concentrate and the dead-state equilibrium than the difference between the growth volume and the dead-state equilibrium.

\subsubsection{Exergy of algal concentrate and discharge water}

The specific exergy of the algal concentrate is calculated using the relations in Equations (7) and (8) and the results are listed in Table C-2. The specific exergy of the algal concentrate in these cases is 8-47 times greater than that of the growth volume, which quantifies the increased volumetric usefulness of the concentrate. The exergy of the discharge water is listed in Table C-3. by,

The exergy balance for the harvesting system is characterized 


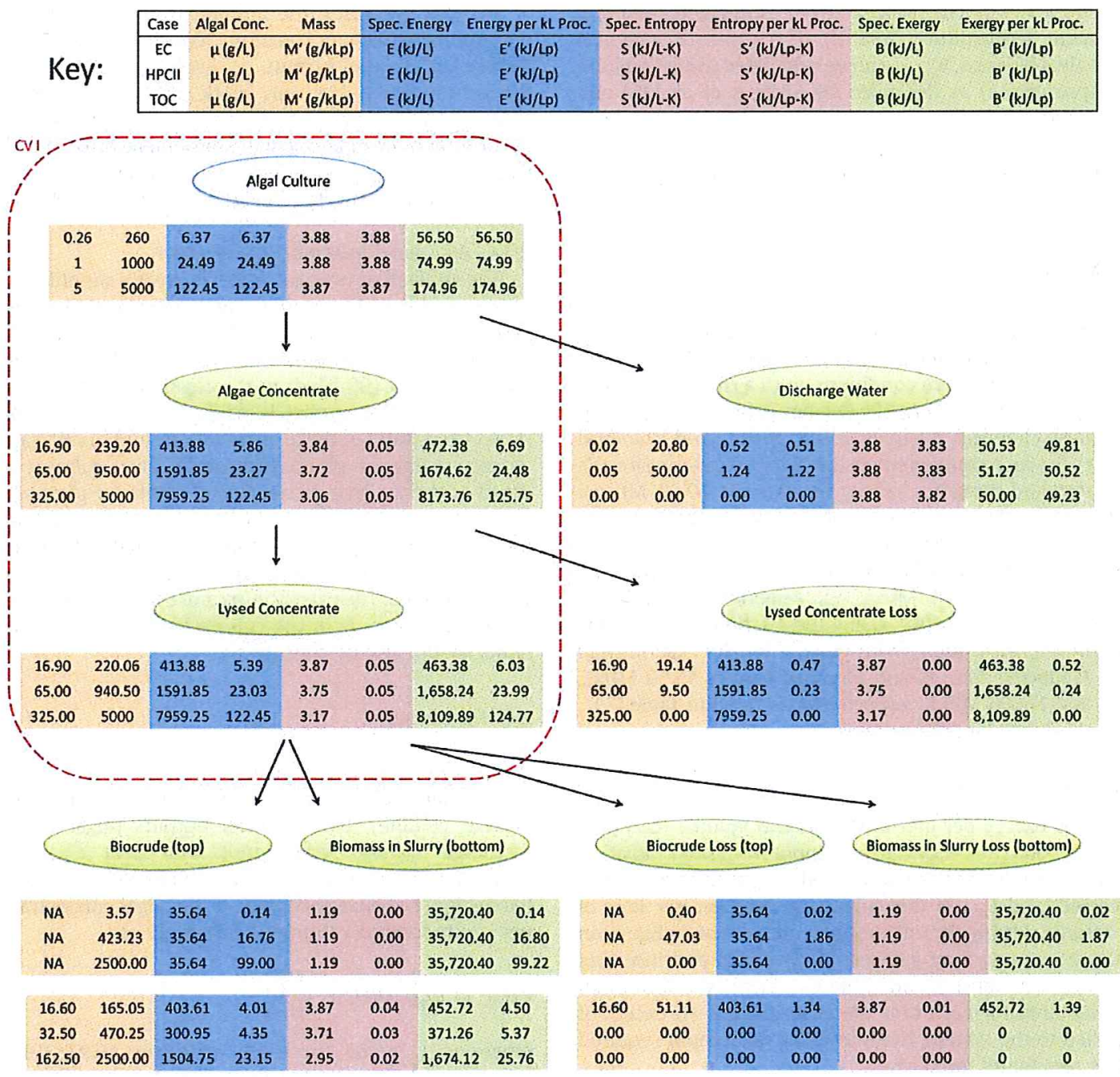

Fig. 3. Mass, energy, entropy, and exergy properties of each intermediate product (assumed to be ideal solutions) in the algal biofuel production pathway of the Experimental Case (EC), Highly Productive Case II (HPCII), and the Idealized Case (IC).

$\dot{B}_{\mathrm{DW}}+\dot{B}_{\mathrm{AC}}=\dot{B}_{\mathrm{GV}}+\dot{W}_{\mathrm{in}}-T_{0} \dot{S}_{\mathrm{gen}} \quad\left[\frac{\mathrm{MJ}}{\mathrm{kL}_{\mathrm{p}}}\right]$

where $B$ is the exergy per liter processed of the discharge water (DW), algal concentrate (AC), and growth volume (GV), $\dot{W}_{\text {in }}$ is the work input per liter processed, and $\dot{S}_{\text {gen }}$ is the entropy generation per liter processed. Setting the entropy generation term in Equation (12) equal to zero and inserting exergy data listed in Table 3 yields the minimum work input required for each case, and these values are also listed in Table 3. The minimum work input required is directly related to the algal concentration, with greater concentrations yielding a greater amount of mixing entropy, therefore requiring a greater work input for separation.

For real processes, the amount of entropy generation can be determined by solving Equation (12) using the actual work that was performed on the system (listed in Table 3). The work input for harvesting in the Experimental Case and the Highly Productive Case II is $22.82 \mathrm{MJ} / \mathrm{kL}_{\mathrm{p}}$ and $0.96 \mathrm{MJ} / \mathrm{kL}_{\mathrm{p}}$, respectively. The work input in the Idealized Case is assumed to be the minimum amount required, as calculated above.
2.4.4. Additional parameters to be considered for harvesting

Real harvesting processes are affected by electrostatic forces that exist between algal cells in the growth volume and by viscous drag that opposes algal cell motion through the growth volume. These forces have been neglected by assuming ideal solutions and, as a result, it the minimum work required for a real process will be greater than that calculated here. The potential "free work" input from gravity or use of chemical flocculation methods should be considered. Finally, as demonstrated in $[5,30]$, the cell structure and chemical composition of algae can change during processing, and this effect should be considered in future models.

\subsection{Lysing}

As described in $[1,5,30]$, cell lysing is accomplished by exposing algal cells to a series of electrical pulses, which compromise the cell membrane enabling extraction of the neutral lipids. Lysing brings the algal concentrate closer to equilibrium with the dead-state environment by compromising barriers (cell membranes) between the concentrated material and the dead-state, thereby 

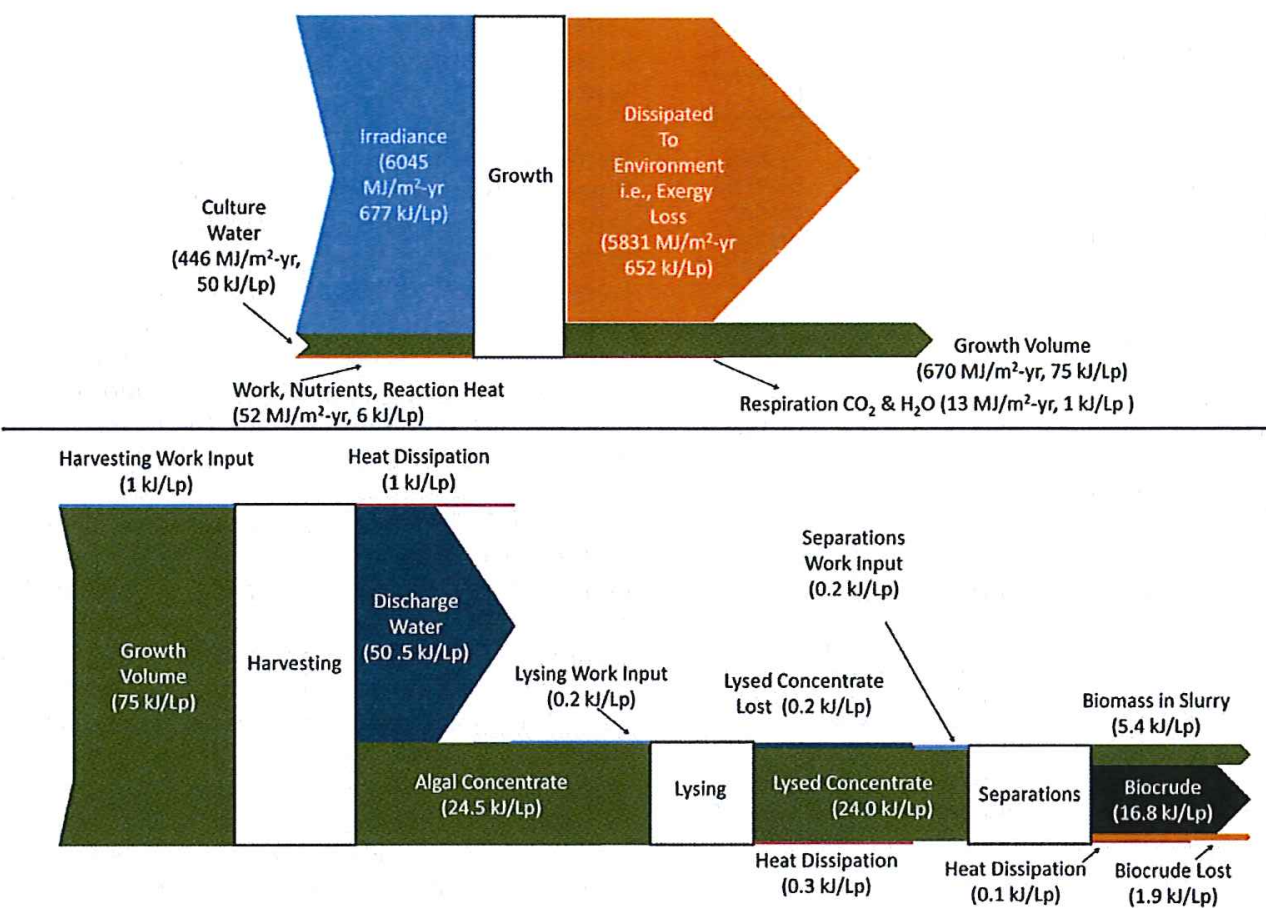

Fig. 4. Sankey diagram of the exergy flows for the Highly Productive Case II. Top: Exergy inputs and outputs for growth. Bottom: Exergy flows for harvesting, lysing, and separations. ${ }^{*}$ Scales are different for the top and bottom figures.

increasing the entropy of the system. While this process generally opposes the desired progression "down" the entropy ladder, lysing is necessary because the cell membranes must be broken to enable the neutral lipids to be separated from the non-lipid biomass, an overall process that reduces the specific entropy (see "Separations"). The lysed biomass and lysing loss (which is

Table 3

Energy, entropy, and exergy summary for harvesting.

\begin{tabular}{|c|c|c|c|}
\hline & $\mathrm{EC}$ & HPCII & IC \\
\hline \multicolumn{4}{|l|}{ Discharge water } \\
\hline Algal concentration $(g / L)$ & 0.02 & 0.05 & 0.00 \\
\hline Algal mass per $\mathrm{kL}$ processed $\left(\mathrm{g} / \mathrm{kL}_{\mathrm{p}}\right)$ & 20.80 & 50.00 & 0.00 \\
\hline Specific energy content (MJ/kL) & 0.52 & 1.24 & 0.00 \\
\hline Energy content per kL processed $\left(M J / k L_{p}\right)$ & 0.51 & 1.22 & 0.00 \\
\hline Specific entropy (kJ/L-K) & 3.88 & 3.88 & 3.88 \\
\hline Entropy per kL processed $\left(\mathrm{kJ} / \mathrm{L}_{\mathrm{p}}-\mathrm{K}\right)$ & 3.83 & 3.83 & 3.82 \\
\hline Specific exergy (MJ/kL) & 50.53 & 51.27 & 50.00 \\
\hline Exergy per kL processed $\left(\mathrm{MJ} / \mathrm{kL}_{\mathrm{p}}\right)$ & 49.81 & 50.52 & 49.23 \\
\hline \multicolumn{4}{|l|}{ Algal concentrate } \\
\hline Algal concentration $(\mathrm{g} / \mathrm{L})$ & 16.90 & 65.00 & 325.00 \\
\hline Algal mass per $k L$ processed $\left(g / k L_{p}\right)$ & 239.20 & 950.00 & 5000.00 \\
\hline Specific energy content (MJ/kL) & 413.88 & 1591.85 & 7959.25 \\
\hline Energy content per kL processed $\left(\mathrm{MJ} / \mathrm{kL}_{\mathrm{p}}\right)$ & 5.86 & 23.27 & 122.45 \\
\hline Specific entropy $(\mathrm{kJ} / \mathrm{L}-\mathrm{K})$ & 3.84 & 3.72 & 3.06 \\
\hline Entropy per kL processed $\left(\mathrm{kJ} / \mathrm{L}_{\mathrm{p}}-\mathrm{K}\right)$ & 0.05 & 0.05 & 0.05 \\
\hline Specific exergy (MJ/kL) & 472.38 & 1674.62 & 8173.76 \\
\hline Exergy per kL processed $\left(\mathrm{MJ} / \mathrm{kL}_{\mathrm{p}}\right)$ & 6.69 & 24.48 & 125.75 \\
\hline \multicolumn{4}{|l|}{ Harvesting Process } \\
\hline Exergy input (GV) (MJ/kL $)$ & 56.4970 & 71.9898 & 174.9575 \\
\hline Exergy output (conc. \& DW) (MJ/kL $L_{p}$ ) & 56.4980 & 71.9938 & 174.9809 \\
\hline Entropy input $(\mathrm{GV})\left(\mathrm{kJ} / \mathrm{L}_{\mathrm{p}}-\mathrm{K}\right)$ & 3.88379 & 3.88192 & 3.87180 \\
\hline Entropy output (AC \& DW) $\left(\mathrm{kJ} / \mathrm{L}_{\mathrm{p}}-\mathrm{K}\right)$ & 3.88379 & 3.88191 & 3.87172 \\
\hline Minimum work input required $\left(\mathrm{MJ} / \mathrm{kL}_{\mathrm{p}}\right)$ & 0.0010 & 0.0040 & 0.0234 \\
\hline Work input $\left(\mathrm{MJ} / \mathrm{kL}_{\mathrm{p}}\right)$ & 22.8141 & 0.9550 & 0.0234 \\
\hline Entropy generation $\left(\mathrm{k} J / \mathrm{L}_{\mathrm{p}}-\mathrm{K}\right)$ & 0.0766 & 0.0032 & 0.0000 \\
\hline
\end{tabular}

compositionally equivalent to the lysed biomass, but not recovered during the lysing process) are modeled as an ideal solution of triglyceride (TAG, specifically glyceryl trioleate), non-lipid biomass (BM), and water.

\subsubsection{Lysing energy balance}

The lysing process consists of one material input (algal concentrate), two material outputs (lysed concentrate and lysing loss), work input, and heat dissipation. It is assumed that the overall energy content of the algal biomass is unaffected during lysing. The energy content of the lysed concentrate, É $D_{\mathrm{LC}}$, can be calculated as,

$E D_{\mathrm{LC}}=\varphi_{\text {cellys }} \cdot E D_{\mathrm{AC}} \quad\left[\frac{\mathrm{kJ}}{\mathrm{L}_{\mathrm{p}}}\right]$

where $\varphi_{\text {cellys }}$ is the cell lysing efficiency. The energy content of the lysed concentrate and lysing loss are listed in Table 4 for each of the three cases. To satisfy the first law, it is assumed that all electrical energy consumed during lysing is dissipated as heat loss (either from the electrical components or the algal concentrate).

\subsubsection{Entropy of the lysed concentrate and lysing loss}

The entropy of the lysed concentrate (LC) and lysing loss (LL) can be calculated from Equations (5) and (6) and the relevant data are listed in Tables C-4 and C-5. The lysing process is modeled as,

$$
\begin{aligned}
& n_{\mathrm{H}_{2} \mathrm{O}} \mathrm{H}_{2} \mathrm{O}+\mathrm{C}_{106} \mathrm{H}_{181} \mathrm{O}_{45} \mathrm{~N}_{15} \mathrm{P} \rightarrow n_{\mathrm{H}_{2} \mathrm{O}} \mathrm{H}_{2} \mathrm{O}+n_{\mathrm{TAG}} \mathrm{C}_{57} \mathrm{H}_{104} \mathrm{O}_{6} \\
& \quad+n_{\mathrm{BS}} \mathrm{CH}_{w} \mathrm{O}_{x} \mathrm{~N}_{y} \mathrm{P}_{z}
\end{aligned}
$$

where $n$ is the number of moles of water, TAG, and non-lipid biomass (BS). For the Experimental Case, the neutral lipid content was estimated to be $1.8 \%$ by HPLC [5], and all of the neutral lipids are assumed to be TAG for this analysis (TAGF $=1$ ). The lipid fraction of the Highly Productive Case II and Idealized Case is assumed to 
Table 4

Energy, entropy, and exergy summary for lysing.

\begin{tabular}{|c|c|c|c|}
\hline & $\mathrm{EC}$ & HPCII & IC \\
\hline \multicolumn{4}{|l|}{ Lysed concentrate } \\
\hline Algal concentration $(g / L)$ & 16.90 & 65.00 & 325.00 \\
\hline Algal mass per $k L$ processed $\left(g / k L_{p}\right)$ & 220.06 & 940.50 & 5000.00 \\
\hline Specific energy content (MJ/kL) & 413.88 & 1591.85 & 7959.25 \\
\hline Energy content per $\mathrm{kL}$ processed $\left(\mathrm{MJ} / \mathrm{KL}_{\mathrm{p}}\right)$ & 5.39 & 23.03 & 122.45 \\
\hline Specific entropy $(\mathrm{kJ} / \mathrm{L}-\mathrm{K})$ & 3.87 & 3.75 & 3.17 \\
\hline Entropy per $k L$ processed $\left(\mathrm{kJ} / \mathrm{L}_{\mathrm{p}}-\mathrm{K}\right)$ & 0.05 & 0.05 & 0.05 \\
\hline Specific exergy (MJ/kL) & 463.38 & 1658.24 & 8109.89 \\
\hline Exergy per kL processed $\left(\mathrm{MJ} / \mathrm{kL}_{\mathrm{p}}\right)$ & 6.03 & 23.99 & 124.77 \\
\hline \multicolumn{4}{|l|}{ Lysing loss } \\
\hline Algal concentration $(\mathrm{g} / \mathrm{L})$ & 16.90 & 65.00 & 325.00 \\
\hline Algal mass per $k L$ processed $\left(g / k_{p}\right)$ & 19.14 & 9.50 & 0.00 \\
\hline Specific energy content (MJ/kL) & 413.88 & 1591.85 & 7959.25 \\
\hline Energy content per kL processed (MJ/kL $\left.L_{p}\right)$ & 0.47 & 0.23 & 0.00 \\
\hline Specific entropy $(\mathrm{kJ} / \mathrm{L}-\mathrm{K})$ & 3.87 & 3.75 & 3.17 \\
\hline Entropy per kL processed $\left(\mathrm{kJ} / \mathrm{L}_{\mathrm{p}}-\mathrm{K}\right)$ & 0.00 & 0.00 & 0.00 \\
\hline Specific exergy (MJ/kL) & 463.38 & 1658.24 & 8109.89 \\
\hline Exergy per kL processed (MJ/kL $\left.\mathrm{L}_{\mathrm{p}}\right)$ & 0.52 & 0.24 & 0.00 \\
\hline \multicolumn{4}{|l|}{ Lysing process } \\
\hline Exergy input $\left(\mathrm{MJ} / \mathrm{kL}_{\mathrm{p}}\right)$ & 6.6860 & 24.4753 & 125.7501 \\
\hline Exergy output $\left(\mathrm{MJ} / \mathrm{kL}_{\mathrm{p}}\right)$ & 6.5585 & 24.2358 & 124.7676 \\
\hline Entropy input $(A C)\left(k J / L_{p}-K\right)$ & 0.05437 & 0.05436 & 0.04704 \\
\hline Entropy output (LC \& LW) $\left(\mathrm{kJ} / \mathrm{L}_{\mathrm{p}}-\mathrm{K}\right)$ & 0.05482 & 0.05487 & 0.04880 \\
\hline Minimum work input needed $\left(\mathrm{MJ} / \mathrm{kL}_{\mathrm{p}}\right)$ & 0 & 0 & 0 \\
\hline Work input $\left(\mathrm{MJ} / \mathrm{kL}_{\mathrm{p}}\right)$ & 3.80 & 0.21 & 0 \\
\hline Entropy generation $\left(\mathrm{kJ} / \mathrm{L}_{\mathrm{p}}-\mathrm{K}\right)$ & 0.0132 & 0.0015 & 0.0033 \\
\hline
\end{tabular}

be $50 \%$, all of which is assumed to be TAG. Therefore, for the Experimental Case, $n_{\mathrm{TAG}}=0.05 \mathrm{~mol}, n_{\mathrm{BS}}=103.21 \mathrm{~mol}, w=1.70$, $x=0.43, y=0.15$, and $z=0.01$. For the Highly Productive Case II and Idealized Case, $n_{\mathrm{TAG}}=1.36 \mathrm{~mol}, n_{\mathrm{BS}}=28.3 \mathrm{~mol}, w=1.38, x=1.30$, $y=0.53$, and $z=0.04$. The standard molar entropy of the triglyceride (TAG) and non-lipid biomass (BM) can be calculated by the relations provided by Battley [21]. These calculations yield $s_{\mathrm{TAG}}^{\circ}=1169 \mathrm{~J} / \mathrm{mol}-\mathrm{K}$ and $s_{\mathrm{BM}_{\mathrm{EC}}}^{\circ}=30 \mathrm{~J} / \mathrm{mol}-\mathrm{K}$ for the Experimental Case and $s_{\mathrm{TAG}}^{\circ}=1169 \mathrm{~J} / \mathrm{mol}-\mathrm{K}$ and $s_{\mathrm{BM} \text { наст тос }}^{\circ}=$ $57.81 \mathrm{~J} / \mathrm{mol}-\mathrm{K}$ for the Highly Productive Case II and Idealized Case. The specific entropy of the lysed concentrate is greater than that of the un-lysed algal concentrate for each of the three cases. This result reflects the impact of including a third component in the ideal solution model and agrees, in principle, with the increased entropy that is expected due to rupturing the cell membranes during lysing.

\subsubsection{Exergy of the lysed concentrate and lysing loss}

The exergy of the lysed concentrate and the lysing loss can be calculated using the relations in Equations (7) and (8) for a threepart solution. The standard chemical exergy and HHV of triglyceride (TAG) and non-lipid biomass (BM) are calculated in Appendix $B$. The exergy of the lysed concentrate is lower than that of the algal concentrate for all cases (due to the increase in entropy). The exergy balance for the lysing process is characterized by,

$\dot{E}_{\mathrm{LC}}+\dot{B}_{\mathrm{LL}}=\dot{B}_{\mathrm{AC}}+\dot{W}_{\text {in }}-T_{0} \dot{S}_{\text {gen }}$

where $B$ is the exergy per liter processed of the lysed concentrate (LC), lysing loss (LL), and algal concentrate (AC), $\dot{W}_{\text {in }}$ is the work input per liter processed, and $S_{\text {gen }}$ is the entropy generation per liter of processed volume. Setting the entropy generation term in Equation (15) equal to zero and inserting exergy data listed in Table 4 yields the minimum work input required for each case, and these values are also listed in Table 4. Since the exergy of the lysed concentrate and lysing loss are less than that of the algal concentrate, the minimum work input is assumed to be zero. This result is an artifact of the ideal solution assumption. For real processes, the amount of entropy generation can be determined by solving Equation (15) using the actual work that was performed on the system (listed in Table 4).

The increased entropy associated with rupturing cell membranes should result in a reduced exergy (cf. Equation (1)). However; the exergy associated with energy stored in living biological structures, such as membranes, is not specifically included in the exergy calculation here, which assumes ideal solutions. The exergy loss that occurs during lysing is the result of calculating the change in exergy indirectly as the difference between the exergy of a two-part ideal solution (the algal concentrate) and a three-part ideal solution (the lysed concentrate). Since the three-part solution is in a higher entropy state (more mixed), it contains less exergy.

\subsubsection{Additional parameters to be considered for lysing}

The ideal solution assumption imparts significant divergence from reality for lysing, as lysing is specifically designed to compromise cell membranes that exist to preserve compartmentalization. As a result, it was calculated that no work is required for the lysing process. In reality, the minimum work input required for lysing is the minimum amount of energy required to compromise the cell membrane. The mechanical properties of lipid vesicle membranes and membranes in animal cells have been measured, including under the application of strong electric fields [31-34]. Electromechanical pulsing is intended to create a mechanical stress to compromise the cell membrane, and therefore the results from those studies provide a basis for comparison of algal cell properties in future models.

\subsection{Separations}

Biocrude is recovered from the algal biomass during the separations process. There are several techniques available for separating neutral lipids from algal biomass, including solvent extraction on dry biomass and wet extraction processes [1,5,35]. In the experiments, biocrude was recovered using a membrane, while in the Highly Productive Case II and Idealized Case models, the specific technology used for separations is not specified.

\subsubsection{Separations energy balance}

The separations process consists of one material input (lysed concentrate), four material outputs (biocrude (triglyceride), biocrude loss, post-extraction biomass slurry, and post-extraction biomass slurry loss), work input, and heat output. The biocrude loss and the post-extraction biomass slurry loss are compositionally equivalent to their recovered counterparts. The energy content of the biocrude can be calculated as,

$$
\dot{E}_{\mathrm{BC}}=\dot{M}_{\mathrm{LM}} \cdot \varphi_{\mathrm{sep}} \cdot \mathrm{HHV}_{\mathrm{BC}} \quad\left[\frac{\mathrm{MJ}}{\mathrm{kL}_{\mathrm{p}}}\right]
$$

and the energy content of the biocrude loss can be calculated as,

$$
E^{\prime} D_{\mathrm{BL}}=\dot{M}_{\mathrm{LM}} \cdot \mathrm{LF} \cdot \mathrm{TAGF} \cdot \mathrm{HHV} V_{\mathrm{BC}}-E_{\mathrm{BC}} \quad\left[\frac{\mathrm{MJ}}{\mathrm{kL}}\right]
$$

where $\dot{M}_{\mathrm{LM}}$ is the mass of lysed algae, $\varphi_{\text {sep }}$ is the separations efficiency, $\mathrm{HHV}_{\mathrm{BC}}$ is the higher heating value of biocrude $(39.6 \mathrm{MJ} / \mathrm{kg})$, LF is the lipid fraction, and TAGF is the triglyceride fraction (cf. [17] for details on the nomenclature). The energy content of the biomass slurry, É $D_{\mathrm{BS}}$, can be calculated as,

$\hat{E}_{\mathrm{BS}}=\dot{M}_{\mathrm{LM}} \cdot(1-\mathrm{LF}) \cdot \varphi_{\mathrm{Sep}_{\mathrm{BS}}} \cdot \mathrm{HHV}_{\mathrm{BS}}\left[\frac{\mathrm{MJ}}{\mathrm{kL}_{\mathrm{p}}}\right]$ 
and the energy content of the biomass slurry loss, É $D_{\mathrm{BSL}}$, can be calculated as,

$$
\dot{E} D_{\mathrm{BSL}}=\dot{M}_{\mathrm{LM}} \cdot(1-\mathrm{LF}) \cdot \mathrm{HHV}_{\mathrm{BS}}-\dot{E} D_{\mathrm{BS}} \quad\left[\frac{\mathrm{MJ}}{\mathrm{kL}_{\mathrm{p}}}\right]
$$

where $\varphi_{\mathrm{Sep}_{\mathrm{BS}}}$ is the separations efficiency of the post-extraction biomass and $H H V_{B S}$ is the higher heating value of the biomass in slurry. The biomass separations efficiency is the amount of algal biomass recovered after separations divided by the amount of nonlipid biomass present before separations. This was assumed to be 0.75, 1, and 1 for the Experimental Case, Highly Productive Case II, and Idealized Case, respectively. Table 5 lists the results for the energy content of each of the four material outputs.

\subsubsection{Entropy of the biocrude and post-extraction biomass slurry}

As was done for the intermediate products above, the entropy of the biocrude and post-extraction biomass slurry can be calculated from Equations (5) and (6) and the relevant data are listed in

Table 5

Energy, entropy, and exergy summary for separations.

\begin{tabular}{|c|c|c|c|}
\hline & $\mathrm{EC}$ & HPCII & IC \\
\hline \multicolumn{4}{|l|}{ Post-extraction biomass slurry } \\
\hline $\begin{array}{l}\text { Higher heating value of biomass in } \\
\text { slurry }(\mathrm{MJ} / \mathrm{kg})\end{array}$ & 24.32 & 9.26 & 9.26 \\
\hline Algal concentration $(\mathrm{g} / \mathrm{L})$ & 16.60 & 32.50 & 162.50 \\
\hline Algal mass $\left(g / \mathrm{kL}_{\mathrm{p}}\right)$ & 165.00 & 470.25 & 2500.00 \\
\hline Specific energy content (MJ/kL) & 403.61 & 300.95 & 1504.75 \\
\hline Energy content $\left(\mathrm{MJ} / \mathrm{kL}_{\mathrm{p}}\right)$ & 23.15 & 4.35 & 4.01 \\
\hline Specific entropy (kJ/L-K) & 3.87 & 3.71 & 2.95 \\
\hline Entropy per kL processed $\left(\mathrm{kJ} / \mathrm{L}_{\mathrm{p}}-\mathrm{K}\right)$ & $3.78 \mathrm{E}-02$ & $2.68 \mathrm{E}-02$ & $2.27 \mathrm{E}-02$ \\
\hline Specific exergy (MJ/kL) & 452.72 & 371.26 & 1674.12 \\
\hline Exergy per kL processed $\left(\mathrm{MJ} / \mathrm{kL}_{\mathrm{p}}\right)$ & 4.50 & 5.37 & 25.76 \\
\hline \multicolumn{4}{|l|}{ Post-extraction biomass slurry loss } \\
\hline Algal concentration (g/L) & 16.60 & 65.00 & 325.00 \\
\hline Algal mass $\left(\mathrm{g} / \mathrm{kL}_{\mathrm{p}}\right)$ & 51.11 & 0.00 & 0.00 \\
\hline Total mass (kg/L) & 1.00 & 1.00 & 1.00 \\
\hline Specific energy content (MJ/kL) & 403.61 & 300.95 & 1504.75 \\
\hline Energy content $\left(M J / k L_{p}\right)$ & 1.31 & 0.00 & 0.00 \\
\hline Specific entropy (kJ/L-K) & 3.87 & 0.00 & 0.00 \\
\hline Entropy per $k \mathrm{~L}$ processed $\left(\mathrm{kJ} / \mathrm{L}_{\mathrm{p}}-\mathrm{K}\right)$ & 0.0126 & 0.00 & 0.00 \\
\hline Specific exergy (MJ/kL) & 452.72 & 0.00 & 0.00 \\
\hline Exergy per kL processed $\left(M J / k L_{p}\right)$ & 1.39 & 0.00 & 0.00 \\
\hline \multicolumn{4}{|l|}{ Biocrude } \\
\hline Higher heating value TAG (MJ/kg) & 39.60 & 39.60 & 39.60 \\
\hline Biocrude density (g/L) & 0.90 & 0.90 & 0.90 \\
\hline Biocrude yield $\left(\mathrm{g} / \mathrm{kL}_{\mathrm{p}}\right)$ & 3.57 & 423.23 & 2500.00 \\
\hline Specific energy content (MJ/kL) & 35.64 & 35.64 & 35.64 \\
\hline Energy content $\left(\mathrm{MJ} / \mathrm{kL}_{\mathrm{p}}\right)$ & 0.14 & 16.76 & 99.00 \\
\hline Specific entropy (kJ/L-K) & 1.19 & 1.19 & 1.19 \\
\hline Entropy per kL processed $\left(k J / L_{p}-K\right)$ & $4.71 \mathrm{E}-06$ & $5.59 \mathrm{E}-04$ & $3.30 \mathrm{E}-03$ \\
\hline Specific exergy (MJ/kL) & $35,720.00$ & $35,720.00$ & $35,720.00$ \\
\hline Exergy per kL processed $\left(\mathrm{MJ} / \mathrm{kL}_{\mathrm{p}}\right)$ & 0.14 & 16.80 & 99.22 \\
\hline \multicolumn{4}{|l|}{ Biocrude loss } \\
\hline Higher heating value TAG (MJ/kg) & 39.60 & 39.60 & 39.60 \\
\hline Biocrude loss (g/kL $)$ & 0.40 & 47.03 & 0.00 \\
\hline Specific energy content (MJ/kL) & 35.64 & 35.64 & 35.64 \\
\hline Energy content $\left(\mathrm{MJ} / \mathrm{kL}_{\mathrm{p}}\right)$ & 0.02 & 1.86 & 0.00 \\
\hline Specific entropy (kJ/L-K) & 1.19 & 1.19 & 1.19 \\
\hline Entropy per $k \mathrm{~L}$ processed $\left(k \mathrm{~J} / \mathbf{L}_{\mathbf{p}}-\mathrm{K}\right)$ & $5.23 \mathrm{E}-07$ & $6.21 \mathrm{E}-05$ & $0.00 \mathrm{E}+00$ \\
\hline Specific exergy (MJ/kL) & 35,720 & 35,720 & 35,720 \\
\hline Exergy per kL processed $\left(M J / k L_{p}\right)$ & 0.02 & 1.87 & 0.00 \\
\hline \multicolumn{4}{|l|}{ Separations process } \\
\hline Exergy input $\left(\mathrm{MJ} / \mathrm{kL}_{\mathrm{p}}\right)$ & 6.0339 & 23.9934 & 124.7676 \\
\hline Exergy output $\left(\mathrm{MJ} / \mathrm{k} \mathrm{L}_{\mathrm{p}}\right)$ & 6.0523 & 24.0358 & 124.9790 \\
\hline Entropy input $(\mathrm{LC})\left(\mathrm{kJ} / \mathrm{L}_{\mathrm{p}}-\mathrm{K}\right)$ & 0.0504 & 0.0543 & 0.0488 \\
\hline $\begin{array}{l}\text { Entropy output (BS, BS Lost, TAG, } \\
\text { TAG lost) }\left(k J / L_{p}-K\right)\end{array}$ & 0.0504 & 0.0275 & 0.0260 \\
\hline Minimum work input needed $\left(\mathrm{MJ} / \mathrm{kL}_{\mathrm{p}}\right)$ & 0.0184 & 0.0424 & 0.2114 \\
\hline Work input $\left(\mathrm{MJ} / \mathrm{kL}_{\mathrm{p}}\right)$ & 24.2318 & 0.1882 & 0.2114 \\
\hline Entropy generation $\left(\mathrm{kJ} / \mathrm{L}_{\mathrm{p}}-\mathrm{K}\right)$ & 0.0813 & 0.0005 & 0.0000 \\
\hline
\end{tabular}

Tables C-6 and C-8. Similar data are listed in Tables C-7 and C-9 for the post-extraction biomass slurry that is lost and the lost biocrude, respectively.

The specific entropy of the post-extraction biomass is greater than that of the lysed concentrate, as expected, which reflects the greater dilution of the post-extraction slurry. However, the total entropy contained in the post-extraction biomass per $\mathrm{kL}$ of processed volume is less than that for the lysed concentrate because entropy is removed from the material with the separated lipids.

2.6.3. Exergy of the biocrude and post-extraction biomass slurry

The exergy of the recovered biocrude and post-extraction biomass is listed in Table 5 . The exergy balance for separations is characterized by,

$\dot{B}_{\mathrm{BC}}+\dot{B}_{\mathrm{BCL}}+\dot{B}_{\mathrm{BS}}+\dot{B}_{\mathrm{BSL}}=\dot{B}_{\mathrm{LC}}+\dot{W}_{\mathrm{in}}-T_{0} \dot{S}_{\mathrm{gen}}$

where $B$ is the exergy per liter processed of the biocrude (BC), biocrude loss (BCL), biomass in slurry (BS), and lost biomass in slurry (BSL). $W_{\text {in }}$ is the work input per L processed, and $\dot{S}_{\text {gen }}$ is the entropy generation per liter of processed volume. Setting the entropy generation term in Equation (20) equal to zero and inserting exergy data listed in Table 5 yields the minimum work input required for each case, and these values are also listed in Table 5. For real processes, the amount of entropy generation can be determined by solving Equation (20) using the actual work that was performed on the system (listed in Table 5).

\subsubsection{Additional parameters to be considered for separations}

Separation processes usually require a solvent to separate the neutral lipids from the biomass, which is subsequently distilled to recover the biocrude. Therefore, the separations process uses chemical interactions between components in the mixture as the driving force to isolate the biocrude. However, in the firstprinciples model presented here, the products are treated as ideal solutions, which specifically neglect chemical interactions between components. As a result, the first-order results presented here characterize the exergy of the idealized biocrude and postextraction biomass slurry, but do not adequately reflect all of the barriers that must be overcome to separate the biocrude from the lysed concentrate. In the model presented here, all of the neutral lipids were assumed to be triglyceride, while in real systems the neutral lipid fraction will contain a range of lipid species. Changes in cell structure and composition have the potential to impact the exergy of the separated materials, and the results in $[5,30]$ demonstrate the likelihood of neutral lipids degrading during the separations step.

\section{Intermediate product thermodynamic property summary}

Fig. 3 lists the mass, energy, entropy, and exergy of each intermediate product in the algal biofuel production pathway. The data are reported as specific values (with respect to the volume of that intermediate product) and with respect to the amount of processed volume (cf. "Units and process description"). To illustrate the exergy flows associated with the algal biofuel production pathway, a Sankey diagram is shown in Fig. 4 that plots the exergy inputs and outputs for the Highly Productive Case II. Each production step is illustrated with a white box and the amount of exergy associated with each input and output for each step are proportional to the size of the corresponding bar. This diagram conveys the concept of the exergetic efficiency, $\eta_{b}$, which is defined and described below. 


\subsection{Thermodynamic efficiencies}

\subsubsection{Energetic efficiency}

The energetic efficiency, $\eta_{e}$, of the entire system is the direct energy output, $E D_{\text {out }}$, divided by the total energy input to the system, É $T_{\text {in }}$, as shown in Equation (21),

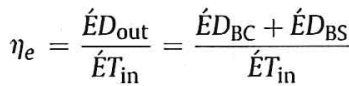

where $E D_{\mathrm{BC}}$ is the energy output of the biocrude and $E D_{\mathrm{BS}}$ is the energy output of the biomass slurry. The total energy input includes chemical, thermal, and solar energy supplied to the system. The energetic efficiency of the growth phase can be characterized as,

$\eta_{e_{\text {growth }}}=\frac{\hat{E} D_{\mathrm{GM}}}{\hat{E} T_{\mathrm{in}_{\text {growth }}}}$

where $E D_{\mathrm{GM}}$ is the energy content of the grown mass and $E T_{\text {in }_{\text {growth }}}$ is the total energy input for growth. The energetic efficiency of processing, $\eta_{e_{\text {proc }}}$, can be defined as,

$\eta_{e_{\text {proc }}}=\frac{\dot{E} D_{\mathrm{BC}}+\dot{E} D_{\mathrm{BS}}}{\dot{E} T_{\mathrm{in}_{\mathrm{proc}}}}=\frac{\dot{E} D_{\mathrm{BC}}+\dot{E}_{\mathrm{BS}}}{\dot{E} D_{\mathrm{GM}}+\dot{W}_{\mathrm{in}_{\mathrm{proc}}}}$

where $W_{\text {in }}$ is is the work input during processing. Results for these energy efficiencies are listed in Table 6.

While the overall energy efficiency is a useful metric to evaluate the conversion of solar energy and work inputs to useful fuel products, it is also valuable to know the ratio of useful energy output divided by energy expense, which is calculated as the firstorder energy return on investment (1st $O$ EROI) (cf. $[1,18]$ ). For the algal biofuel production system, the first-order EROI is therefore,

1st $O$ EROI $=\frac{E ́ D_{\mathrm{BC}}+E^{\prime} D_{\mathrm{BS}}}{\dot{W}_{\mathrm{in}}} \quad[-]$

where $W_{\text {in }}$ is the work input to the system. Using the data in Table 6 , the 1st $O$ EROI for the growth and processing steps of the Experimental Case, Highly Productive Case II, and Idealized Case is $1.7 \times 10^{-3}, 9.8$, and 520, respectively. This result for the Experi-
Table 6

Energetic and exergetic efficiencies for the Experimental Case, Highly Productive Case II, and the Idealized Case.

\begin{tabular}{|c|c|c|c|}
\hline & EC & HPCII & IC \\
\hline Total energy input for growth $\left(\mathrm{kJ} / \mathrm{L}_{\mathrm{p}}\right)$ & $13,327.70$ & 731.68 & 880.11 \\
\hline Total energy input for processing $\left(\mathrm{kJ} / \mathrm{L}_{\mathrm{p}}\right)$ & 50.84 & 1.35 & 0.23 \\
\hline Total energy input $\left(\mathrm{MJ} / \mathrm{kL}_{\mathrm{p}}\right)$ & $13,378.54$ & 733.03 & 880.34 \\
\hline Total work input for growth $\left(\mathrm{kJ} / \mathrm{L}_{\mathrm{p}}\right)$ & 2369.49 & 0.81 & 0.00 \\
\hline Total work input for processing $\left(\mathrm{kJ} / \mathrm{L}_{\mathrm{p}}\right)$ & 50.84 & 1.35 & 0.23 \\
\hline Total work input $\left(\mathrm{kJ} / \mathrm{L}_{\mathrm{p}}\right)$ & 2420.33 & 2.16 & 0.23 \\
\hline Total minimum work input required $\left(\mathrm{kJ} / \mathrm{L}_{\mathrm{p}}\right)$ & 0.02 & 0.05 & 0.23 \\
\hline Energy yield $\left(\mathrm{kJ} / \mathrm{L}_{\mathrm{p}}\right)$ & 4.15 & 21.11 & 122.15 \\
\hline Total exergy input for growth $\left(\mathrm{kJ} / \mathrm{L}_{\mathrm{p}}\right)$ & $12,614.93$ & 732.46 & 873.64 \\
\hline Total exergy input for processing $\left(\mathrm{kJ} / \mathrm{L}_{\mathrm{p}}\right)$ & 50.84 & 1.35 & 0.23 \\
\hline Total exergy input $\left(\mathrm{MJ} / \mathrm{KL}_{\mathrm{p}}\right)$ & $12,665.78$ & 733.81 & 873.88 \\
\hline Exergy yield $\left(\mathrm{kJ} / \mathrm{L}_{\mathrm{p}}\right)$ & 4.64 & 22.17 & 124.98 \\
\hline Growth energy efficiency (-) & $4.78 \mathrm{E}-04$ & 0.03 & 0.14 \\
\hline Processing energy efficiency $(-)$ & $7.3 \mathrm{E}-02$ & 0.82 & 0.996 \\
\hline Overall energy efficiency $(-)$ & $3.1 \mathrm{E}-04$ & 0.03 & 0.14 \\
\hline First-order EROI (-) & 1.7E-03 & 9.77 & 520 \\
\hline Maximum first-order EROI for ideal solutions ( - ) & 214 & 455 & 520 \\
\hline Maximum first-order EROI for a real process (-) & TBD & TBD & TBD \\
\hline Growth exergy efficiency $(-)$ & 4.24E-03 & 0.10 & 0.20 \\
\hline Processing exergy efficiency $(-)$ & $4.32 E-02$ & 0.29 & 0.71 \\
\hline Overall exergy efficiency $(-)$ & 3.67E-04 & 0.03 & 0.14 \\
\hline First-order BROI (-) & $1.92 \mathrm{E}-03$ & 10.3 & 532 \\
\hline Maximum first-order BROI for ideal solutions (-) & 239 & 478 & 532 \\
\hline Maximum first-order BROI for a real process $(-)$ & TBD & TBD & TBD \\
\hline
\end{tabular}

$\dot{W}_{\mathrm{in}_{\min }}=\sum_{\text {all steps }}\left(\dot{W}_{\mathrm{in}_{\min }}\right)=\sum_{\text {all steps }}\left(\dot{W}_{\min _{\mathrm{ls}}}+\dot{W}^{*}\right)\left[\frac{\mathrm{kL}}{\mathrm{L}}\right]$

where $\dot{W}^{*}$ is the work input required for real processes that is in addition to the minimum work input required if the intermediate products are ideal solutions, $W_{\text {min }_{15} \text { (which was determined for }}$ each step in the preceding sections). Equation (25) can be expanded to include growth, harvesting, cell lysing, and separations as,

$$
\dot{W}_{\mathrm{in}_{\min }}=\dot{W}_{\text {min }_{\mathrm{IS} .}}+\dot{W}_{\text {growth }}^{*}+\dot{W}_{\text {harv }}^{*}+\dot{W}_{\text {cellys }}^{*}+\dot{W}_{\text {sep }}^{*}\left[\frac{\mathrm{kJ}}{\mathrm{L}}\right]
$$

The maximum 1st $O$ EROI is therefore,

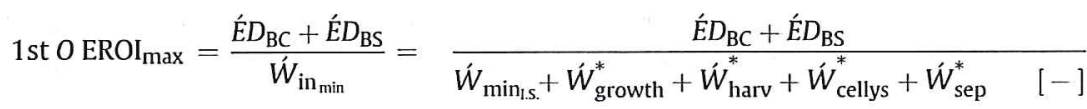

mental Case is $73 \%$ greater than the 1st $O$ EROI reported in $[1,5]$ (which is $9.8 \times 10^{-4}$ ), because the analysis in $[1,5]$ included refining work inputs and assumed a lower post-extraction biomass energy content ( $13.75 \mathrm{MJ} / \mathrm{kg}$ versus $24.21 \mathrm{MJ} / \mathrm{kg}$ ). The 1 st $O$ EROI for the Highly Productive Case described in [1,5], which assumes a greater amount of work input than the Highly Productive Case II, is 1.5 , which is on the same order of magnitude as that calculated for the Highly Productive Case II (9.8).

As stated above, the goal of this analysis is to determine the minimum amount of work input required for operating the biofuel production pathway analytically and compares that to the useful energy output of the system. Based on the results presented above, the minimum work input is best represented as,
As shown in Table 6 , if the intermediate products are ideal solutions ( $\dot{W}^{*}=0$ for all steps), 1 st 0 EROI $\max$ is 455 and 520 for the Highly Productive Case II and the Idealized Case, respectively. Since the analysis presented here only contains work inputs associated with entropy of mixing, a greater amount of work would be required to "unmix" the Idealized Case than the Highly Productive Case II because the Idealized Case contains five times more algae. However, the Idealized Case also has a greater energy yield (slightly more than $5 \times$ ). These differences cause the difference in the 1st $O$ EROI $_{\max }$ for these cases. The 1st $O$ EROI of the Idealized Case is the same as that for the 1st $O \mathrm{EROI}_{\max }$ case because all of the work inputs for the Idealized Case were specified to be the minimum required if the intermediate products were ideal solutions. 


\subsubsection{Exergetic efficiency}

The exergetic efficiency, $\eta_{b}$, of the algal biofuel production system is the exergy output divided by the exergy input for operating the system,

$\eta_{b}=\frac{\dot{B} D_{\text {out }}}{\dot{B} T_{\mathrm{in}}}=\frac{\dot{B} D_{\mathrm{BC}}+\dot{B} D_{\mathrm{BS}}}{\dot{B} T_{\mathrm{in}}}$

where $B D_{\mathrm{BC}}$ is the exergy content of the biocrude, $B D_{\mathrm{BS}}$ is the exergy content of the post-extraction biomass in slurry, and $B T_{\text {in }}$ is the total exergy input to the system. The exergetic efficiency of the growth phase can be characterized as,

$\eta_{b_{\text {growth }}}=\frac{\dot{B} D_{\mathrm{GM}}}{\dot{B} T_{\mathrm{in}_{\text {growth }}}}$

where $B D_{\mathrm{GM}}$ is the exergy content of the grown mass and $B T_{\mathrm{in}} \mathrm{n}_{\text {growth }}$ is the total exergy input for growth. The exergetic efficiency of processing, $\eta_{b_{\text {proc }}}$, can be defined as,

$\eta_{b_{\text {proc }}}=\frac{\dot{B} D_{\mathrm{BC}}+\dot{B} D_{\mathrm{BS}}}{\dot{B} T_{\mathrm{in}_{\mathrm{proc}}}}=\frac{\dot{B} D_{\mathrm{BC}}+\dot{B} D_{\mathrm{BS}}}{\hat{B} D_{\mathrm{GM}}+\dot{W}_{\mathrm{in}_{\mathrm{proc}}}}$

where $W_{\text {in }_{\text {proc }}}$ is the work input during processing. Results for these exergy efficiencies are listed in Table 6.

The exergy return on investment (BROI) is the exergy of the fuels produced divided by exergy expenses (i.e., work input). Therefore, analogous to the energy return on investment, the firstorder BROI (1st $O$ BROI) can be defined for the algal biofuel production system as,

1st $O$ BROI $=\frac{\dot{B} D_{\mathrm{BC}}+\dot{B} D_{\mathrm{BS}}}{\dot{W}_{\text {in }}}[-]$

where $W_{\text {in }}$ is the work input to the system. Using the data in Table 6, the 1st 0 BROI of the Experimental Case, Highly Productive Case II, and Idealized Case is $1.92 \times 10^{-3}, 10.3$, and 532, respectively. The maximum 1 st $O$ BROI can be calculated as, while more realistic values obtained for the Highly Productive Case II were 0.03 and 0.03 , respectively. The goal of any energy providing system is to produce energy products that contain a greater amount of energy (and exergy) than the amount of energy (and exergy) spent during their acquisition. The energy return on investment and exergy return on investment are metrics that characterize the input-output ratio. For the Highly Productive Case II and the Idealized Case (assuming intermediate products were ideal solutions), the maximum first-order EROI and BROI values were calculated to be about $450-550$, indicating that algal biofuel production under these conditions would be very profitable. However, when assuming more realistic work inputs, the first-order EROI and BROI for the Highly Productive Case II (which is still highly optimistic) were about 10 .

It is also important to consider the impact of indirect energy inputs, such as energy embedded in material inputs, which is not included in the first-order EROI or first-order BROI. The secondorder EROI includes indirect energy inputs, in addition to direct energy inputs. Therefore, the second-order EROI is always less than the first-order EROI [36]. The second-order EROI cannot be calculated for the Highly Productive Case II or the Idealized Case because the energy embedded in some material inputs is not known. However, the importance of considering indirect energy inputs can be illustrated by the significant disparity between the first-order EROI of the Highly Productive Case II (9.77), the first-order EROI of the Highly Productive Case described in [1,5] (1.5), and the secondorder EROI for the Highly Productive Case $(0.22)$ calculated in $[1,5]$. These metrics can be used to provide direct comparisons to other energy systems. For example, for oil and gas co-production, the firstand second-order energy return on investment values have been estimated to be $\sim 35$ and $\sim 15$, respectively, and the second-order energy return on investment for coal production has been estimated to be $\sim 80$ [37]. These comparisons demonstrate that, even for a highly optimistic scenario such as the Highly Productive Case II (first-order EROI $=10$ ), or a more realistic scenario such as the Highly Productive Case (first-order EROI $=1.5$ ), the return on investment for algal biofuels will most likely remain lower than that for fossil fuels (e.g., the first-order EROI for oil and gas production is 35).

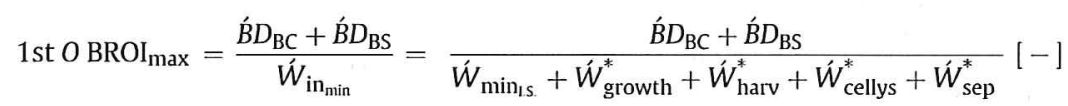

and if all of the intermediate products are assumed to be ideal solutions ( $\dot{W}^{*}=0$ for all steps), the first-order maximum BROI is 478 and 532 for the Highly Productive Case II and Idealized Case, respectively.

\section{Conclusions}

As described in the introduction, the goal of the algal biofuel production pathway, which is common to other biofuel production pathways, is to produce energy-dense, low-entropy fuels from materials with low energy density and high entropy. This study successfully demonstrates these trends, from a first-principles analysis, by characterizing the thermodynamic properties of each intermediate product under the ideal solution assumption.

The maximum energetic and exergetic efficiencies, which were obtained for the Idealized Case, were 0.14 and 0.14 , respectively,
The energy and exergy efficiencies for any real algal biofuel system are expected to be significantly lower than those calculated for the Highly Productive Case II and the Idealized Case. A major research thrust for future work is to determine values of $\dot{W}^{*}$ for each step and incorporate those contributions into the calculation of the maximum possible energy and exergy efficiencies of the system (cf. Equations (27) and (32)).

The results presented in this analysis outline a framework for calculating the maximum possible thermodynamic efficiencies of producing fuel from algae and provide initial estimates for the thermodynamic properties of the intermediate products. However, greater detail is needed to accurately model each processing step, by including, among other things, all energy inputs required for cultivation, radiation scattering in water, electrostatic and viscous forces during harvesting, losses that occur during lysing, and chemical interactions that govern separations, as each of these 
effects were neglected in the present study, but are unavoidable in reality. Determining accurate models for each of these steps would enable an analytical assessment of the maximum theoretical thermodynamic efficiencies of a real algal biofuel production system, measures that would be quite valuable for assessing the fundamental feasibility of algal biofuels and for evaluating the efficiency of real production pathways.

\section{Acknowledgements}

We would like to thank Dr. Jeanne Stachowiak, Dr. Phil Schmidt, and Dr. Janet Ellzey for discussions regarding this analysis and Dr. Rodney Ruoff, who co-advised the dissertation from which this work originated. We would like to thank OpenAlgae LLC for funding. We would also like to thank Patrice Palmer and Theresa Caillouet for assistance preparing the manuscript and Benjamin Gully, Colin Smith, and Aaron Townsend for providing helpful input.

\section{Appendix A. Growth volume energy and exergy balance}

Energy inputs to growth

The overall energy balance associated with the growth phase can be summarized as,

$I+W_{\text {mix }}=I_{\text {ref }}+E D_{\mathrm{GV}}+Q_{\mathrm{abs}}$

where $I$ is the incident radiation, $W_{\text {mix }}$ is the work input from mixing, $I_{\text {ref }}$ is the reflected irradiance, $E D_{G V}$ is the energy retained in the growth volume, and $Q_{\mathrm{abs}}$ is the heat absorbed (via multiple mechanisms described below), which is in-turn dissipated to the environment.

Irradiance and Conversion to Biomass: Based on the data used by Weyer et al., the incident radiation for the Experimental Case, Highly Productive Case II, and Idealized Case, were specified to be $6500 \mathrm{MJ} /$ $\mathrm{m}^{2}-\mathrm{yr}, 6500 \mathrm{MJ} / \mathrm{m}^{2}-\mathrm{yr}$, and $11,616 \mathrm{MJ} / \mathrm{m}^{2}-\mathrm{yr}$, respectively [8]. The amount of this irradiance, $I$, that is converted to energy contained in the growth volume (as algal biomass) can be calculated from,

$E D_{\mathrm{GV}}=(\mathrm{I} \cdot \mathrm{PAR} \cdot \mathrm{PTE} \cdot \mathrm{PUE} \cdot \alpha \cdot(1-\mathrm{CoL}) \cdot \tau) \cdot \frac{t_{c}}{d} \quad\left[\frac{\mathrm{kJ}}{\mathrm{L}}\right]$

where PAR is the photosynthetically active radiation, PTE is the photon transmission efficiency, and PUE is the photon-utilization efficiency (cf. Weyer et al. [8]). The cultivation time is $t_{c}, d$ is the pond depth, and $\alpha, \operatorname{CoL}$, and $\tau$, are defined below. For convenience in characterizing the Experimental Case (where most terms in Equation (A-2) are unknown, but can be calculated when combined), $\beta$ is defined as,

$\beta=\mathrm{PTE} \cdot \mathrm{PUE} \cdot \alpha \cdot(1-\mathrm{COL}) \cdot \tau$

and was determined indirectly to be $9.74 \times 10^{-4}$. For the Highly Productive Case II and the Idealized Case, $\beta$ is 0.04 and 0.31 , respectively. In Equation (A-2), the term $\alpha$ characterizes the efficiency by which photons used for photosynthesis are converted to glucose through the following reaction (Z-scheme photosynthesis),

$\mathrm{CO}_{2}+\mathrm{H}_{2} \mathrm{O}+8 \gamma \rightarrow \mathrm{CH}_{2} \mathrm{O}+\mathrm{O}_{2}+Q_{\text {ex }}$

The amount of excess heat, $Q_{e x}$, can be determined by conducting an enthalpy balance on Equation (A-4), which is,

$h_{\mathrm{CO}_{2}}^{\circ}+h_{\mathrm{H}_{2} \mathrm{O}}^{\circ}+8\left(e_{\gamma}\right)=h_{\mathrm{CH}_{2} \mathrm{O}}^{\circ}+h_{\mathrm{O}_{2}}^{\circ}+Q_{\mathrm{ex}}$

Assuming standard conditions, these enthalpy values reduce to the enthalpy of formation for each term, which are,
$(-393.5)+(-285.8)+8(225.3) \rightarrow(-211.83)+(0)+Q_{e x}\left[\frac{k J}{m o l}\right]$

The enthalpy of formation data were obtained from [27]. Therefore, in addition to the energy used to drive the chemical reaction, there is $1047.4 \mathrm{~kJ}$ of excess photon energy, $Q_{\mathrm{ex}}$ that is absorbed for each mol of glucose produced. The higher heating value of glucose $\left(\mathrm{CH}_{2} \mathrm{O}\right)$ is $467.5 \mathrm{~kJ} / \mathrm{mol}$, represented by $Q_{\text {rel }}$ and calculated from the enthalpy balance at standard conditions of,

$\mathrm{CH}_{2} \mathrm{O}+\mathrm{O}_{2} \rightarrow \mathrm{CO}_{2}+\mathrm{H}_{2} \mathrm{O}+Q_{\text {rel }} \quad\left[\frac{\mathrm{kJ}}{\mathrm{mol}}\right]$

Therefore, $0.26 \mathrm{~kJ}$ of glucose energy are produced for each $\mathrm{kJ}$ of photon energy participating in photosynthesis, and this ratio is incorporated in Equation (A-2) as $\alpha$, which is therefore,

$\alpha=\frac{E_{\text {glucose }}}{E_{\mathrm{PS}_{\text {photon }}}}=\frac{467.5}{8 \cdot 225.3}=0.26$

The cost of living term, CoL, characterizes how much of the glucose energy is consumed for cell maintenance, ranging from 0 in the Idealized Case (with no glucose consumed for cell maintenance) to 0.5 in the Highly Productive Case II. Assuming algae have the stoichiometry defined by Clarens et al. [19] $\left(\mathrm{C}_{106} \mathrm{H}_{181} \mathrm{O}_{45} \mathrm{~N}_{15} \mathrm{P}\right)$, the conversion of glucose to algal biomass can be grossly approximated as,

$$
\begin{aligned}
& 106 \mathrm{CH}_{2} \mathrm{O}+15 \mathrm{NaNO}_{3}+0.5 \mathrm{P}_{2} \mathrm{O}_{5}+Q_{\text {gluc-BM }} \\
& \quad \rightarrow \mathrm{C}_{106} \mathrm{H}_{181} \mathrm{O}_{45} \mathrm{~N}_{15} \mathrm{P}+8 \mathrm{H}_{2} \mathrm{O}+42.75 \mathrm{O}_{2}+15 \mathrm{NaOH}
\end{aligned}
$$

where $Q_{\text {gluc-BM }}$ is heat absorbed during this endothermic reaction. The heating values for algae can be determined using the following reaction

$$
\begin{aligned}
& \mathrm{C}_{106} \mathrm{H}_{181} \mathrm{O}_{45} \mathrm{~N}_{15} \mathrm{P}+130 \mathrm{O}_{2} \rightarrow 106 \mathrm{CO}_{2}+7.5 \mathrm{~N}_{2}+90.5 \mathrm{H}_{2} \mathrm{O} \\
& \quad+0.5 \mathrm{P}_{2} \mathrm{O}_{5}
\end{aligned}
$$

Calculating the heating values (either higher or lower heating value) as the difference between the enthalpies of formation of products and reactants yields,

$$
\begin{aligned}
\mathrm{HV}= & 106 \cdot(-393.5)+90.5\left(h_{f, \text { water }}^{\circ}\right)+0.5(-1492) \\
& -\left(h_{f, \text { algae }}^{\circ}\right)\left[\frac{\mathrm{kJ}}{\mathrm{mol}}\right]
\end{aligned}
$$

Since the enthalpy of formation of algae is not known, the higher heating value, HHV, can be estimated as stated by Clarens et al.,

$$
\begin{aligned}
\mathrm{HHV}= & 35,160 \cdot x_{\mathrm{C}}+116,225 \cdot x_{\mathrm{H}}-11,090 \cdot x_{\mathrm{O}} \\
& +6280 \cdot x_{\mathrm{N}} \quad[\mathrm{kJ} / \mathrm{kg}]
\end{aligned}
$$

where $x$ is the mass fraction of each element (carbon, hydrogen, oxygen, and nitrogen). The HHV for the algae considered here is $24.49 \mathrm{MJ} / \mathrm{kg}(59.12 \mathrm{MJ} / \mathrm{mol})$. Inserting this value into Equation A11 along with the enthalpy of formation of liquid water $(-285.8 \mathrm{~kJ} / \mathrm{mol})$ yields the enthalpy of formation for algae with this stoichiometry, $h_{f, \text { algae }}^{\circ}$, to be $-9.20 \mathrm{MJ} / \mathrm{mol}$. The lower heating value, LHV, can then be determined from Equation (A-11) using the enthalpy of formation of water vapor $(-241.8 \mathrm{~kJ} / \mathrm{mol})$, and is $22.84 \mathrm{MJ} / \mathrm{kg}$. Conducting an energy balance around Equation (A-9) yields, 


$$
\begin{aligned}
& 106(-212)+15(-468)+0.5(-1492)+Q_{\text {gluc }- \text { BM }} \\
& \quad \rightarrow(-9200)+8(-285.8)+42.75(0)+15(-734.9)[\mathrm{kJ}]
\end{aligned}
$$

The heat absorbed during this reaction, $Q_{\text {gluc-BM, }}$ is therefore 7.65 MJ per mol of algae produced. Assuming a negligible energy content of $\mathrm{NaNO}_{3}, \mathrm{P}_{2} \mathrm{O}_{5}$, and $\mathrm{NaOH}$, a first-law analysis of this conversion process yields,

\subsection{MJ glucose energy $+7.65 \mathrm{MJ}$ of heat \\ $\rightarrow 59.12 \mathrm{MJ}$ of algal biomass energy}

which is within $3.7 \%$ of being balanced, sufficient for this analysis. The energy conversion of glucose (with a HHV of $467.5 \mathrm{~kJ} / \mathrm{mol}$ ) to biomass energy is represented by $\tau=59,120 / 106 \cdot 467.5=1.19$.

As an example (and shown in Fig. 2), for the Highly Productive Case II with $6500 \mathrm{MJ} / \mathrm{m}^{2}$-yr of irradiance, $6175 \mathrm{MJ} / \mathrm{m}^{2}$-yr are transmitted into the pond, of which $2828 \mathrm{MJ} / \mathrm{m}^{2}$-yr are within the photosynthetically active spectral region (the non-PAR irradiance is assumed to be absorbed and converted to heat). Of the remaining $2828 \mathrm{MJ} / \mathrm{m}^{2}$ $\mathrm{yr}, 1414 \mathrm{MJ} / \mathrm{m}^{2}$-yr ( $6277 \mathrm{~mol} / \mathrm{m}^{2}$-yr) are utilized for photosynthesis. With a quantum requirement of 8 photons per mol of glucose produced [8], $784.6 \mathrm{~mol} / \mathrm{m}^{2}$-yr of glucose are produced, half of which is consumed for cell maintenance (cost of living). The remaining $392.3 \mathrm{~mol} / \mathrm{m}^{2}$-yr of glucose is converted to $3.70 \mathrm{~mol} / \mathrm{m}^{2}$-yr of algal biomass with an energy content of $218.74 \mathrm{MJ} / \mathrm{m}^{2}$-yr; yielding an overall energy conversion efficiency (of solar energy to algal biomass) of 3.35\%. The equivalent energy conversion efficiency for the Experimental Case and Idealized Case are $0.05 \%$ and $14.2 \%$, respectively.

Electrical energy inputs: The electrical energy consumed for growth was $1406 \mathrm{MJ} / \mathrm{m}^{2}$-yr in the Experimental Case [1]. For the Highly Productive Case II, only mixing energy (estimated to be $99 \mathrm{~J} /$ $\mathrm{L}-d$ ) was included, and resulted in $7.23 \mathrm{MJ} / \mathrm{m}^{2}$-yr. The Idealized Case assumes no electrical energy input.

Reaction water: According to Equation (A-4), $1 \mathrm{~mol}$ of water is consumed for each mol of glucose produced, corresponding to $14.12 \mathrm{~kg} / \mathrm{m}^{2}-\mathrm{yr}$ and $53.13 \mathrm{~kg} / \mathrm{m}^{2}$-yr consumed for the Highly Productive Case II and Idealized Case, respectively. The amount of water consumed for photosynthesis in the Experimental Case is unknown. The internal energy content of water was neglected.

Carbon dioxide: In the Experimental Case, $5.55 \mathrm{~kg} / \mathrm{m}^{2}-\mathrm{yr}$ of carbon dioxide were consumed during growth, although it is unclear how much of this mass was utilized for photosynthesis [1]. Using Equation (A-4), $34.52 \mathrm{~kg} / \mathrm{m}^{2}$-yr and $129.87 \mathrm{~kg} / \mathrm{m}^{2}$-yr of carbon dioxide are consumed in the Highly Productive Case II and Idealized Case, respectively. The amount of carbon dioxide (in $\mathrm{kg}$ ) consumed per $\mathrm{kg}$ of biomass is, 35.97, 3.86, and 1.93 for the Experimental Case, Highly Productive Case II, and Idealized Case, respectively. The carbon dioxide requirements are therefore a function of uptake rates, cost of living, and biomass productivity. The internal energy content of carbon dioxide was neglected.

Sodium nitrate $\left(\mathrm{NaNO}_{3}\right)$ : Nitrogen was supplied to the growth volumes in the experiments in various forms, but the total amount of nitrogen consumed was determined to be $127.4 \mathrm{~g} / \mathrm{m}^{2}-\mathrm{yr}$, which is the nitrogen equivalent of $773.5 \mathrm{~g} / \mathrm{m}^{2}-\mathrm{yr}$ of sodium nitrate [1]. According to Equation (A-9), $4.72 \mathrm{~kg} / \mathrm{m}^{2}$-yr and $35.50 \mathrm{~kg} / \mathrm{m}^{2}$-yr of sodium nitrate are consumed in the Highly Productive Case II and Idealized Case, respectively. The amount of nitrogen (in g) consumed per $\mathrm{kg}$ of biomass is, 826,87 , and 87, for the Experimental Case, Highly Productive Case II, and Idealized Case, respectively. The internal energy content of sodium nitrate was neglected.

Phosphorus pentoxide $\left(\mathrm{P}_{2} \mathrm{O}_{5}\right)$ : Phosphorus was supplied to the growth volumes in the experiments in various forms, but the total amount of phosphorus consumed was determined to be $2.30 \mathrm{~g} / \mathrm{m}^{2}-$ $\mathrm{yr}$, which is the phosphorus equivalent of $5.27 \mathrm{~g} / \mathrm{m}^{2}$-yr of phosphorus pentoxide [1]. Using Equation (A-9), $0.26 \mathrm{~kg} / \mathrm{m}^{2}-\mathrm{yr}$ and $1.98 \mathrm{~kg} / \mathrm{m}^{2}-\mathrm{yr}$ of phosphorus pentoxide are consumed in the Highly Productive Case II and Idealized Case, respectively. The amount of phosphorus (in g) consumed per $\mathrm{kg}$ of biomass is, 7,6, and 6, for the Experimental Case, Highly Productive Case II, and Idealized Case, respectively. The internal energy content of phosphorus pentoxide was neglected.

Culture water: For the experiments, $1.91 \mathrm{~L}$ of water $(1.91 \mathrm{~kg})$ were consumed for every liter processed [5] and this translates to $1134 \mathrm{~kg} / \mathrm{m}^{2}$-yr. For the Highly Productive Case II and Idealized Case, $0.999 \mathrm{~L}(0.99 \mathrm{~kg})$ and $0.995 \mathrm{~L}(0.995 \mathrm{~kg})$ of water are used for each liter of processed volume, and these rates translate to $8923 \mathrm{~kg} / \mathrm{m}^{2}$ yr and $13,376 \mathrm{~kg} / \mathrm{m}^{2}-\mathrm{yr}$.

\section{Energy outputs from growth}

Irradiance (reflected and absorbed): As described above, the majority of the incident radiation is reflected or absorbed as heat. The quantitative proportions of these contributions are unknown in the Experimental Case, which prevents some of the parameters listed in Table $\mathrm{C}-2$ from being calculated. For the Highly Productive Case II and Idealized Case, $325 \mathrm{MJ} / \mathrm{m}^{2}-\mathrm{yr}$ and $0 \mathrm{MJ} / \mathrm{m}^{2}-\mathrm{yr}$ are reflected, $3347 \mathrm{MJ} / \mathrm{m}^{2}-\mathrm{yr}$ and $5320 \mathrm{MJ} / \mathrm{m}^{2}-\mathrm{yr}$ of non-PAR are absorbed, and $1414 \mathrm{MJ} / \mathrm{m}^{2}$-yr and $0 \mathrm{MJ} / \mathrm{m}^{2}$-yr of unutilized photon energy are absorbed, respectively. The absorbed energy is dissipated to the environment via convection and radiation.

Respiration: The amount of incident energy that is converted to glucose and consumed for cell functions via respiration is not known for the Experimental Case. For the Idealized Case, it is assumed that the cost of living is zero, although achieving this assumption is not possible in reality. However, for the Highly Productive Case II, the cost of living is assumed to be $50 \%$ of the glucose produced from photosynthesis, and this process releases $183.4 \mathrm{MJ} / \mathrm{m}^{2}$-yr of heat ( $\left.Q_{\text {resp }}\right), 17.26 \mathrm{~kg} / \mathrm{m}^{2}$-yr of carbon dioxide, and $7.06 \mathrm{~kg} / \mathrm{m}^{2}-\mathrm{yr}$ of water. The internal energy content of carbon dioxide and water were neglected.

Sodium hydroxide ( $\mathrm{NaOH}$ ): According to Equation (A-9), $15 \mathrm{~mol}$ of sodium hydroxide are produced for each mol of algae. For the Experimental Case, Highly Productive Case II, and Idealized Case, the amount of sodium hydroxide produced can be calculated to be $0.04 \mathrm{~kg} / \mathrm{m}^{2}-\mathrm{yr}, 2.22 \mathrm{~kg} / \mathrm{m}^{2}-\mathrm{yr}$, and $16.71 \mathrm{~kg} / \mathrm{m}^{2}-\mathrm{yr}$. The internal energy of sodium hydroxide was neglected.

Oxygen: According to Equation (A-9), $42.75 \mathrm{~mol}$ of oxygen are produced for each mol of algae. For the Experimental Case, Highly Productive Case II, and Idealized Case, the amount of oxygen produced can be calculated to be $0.09 \mathrm{~kg} / \mathrm{m}^{2}-\mathrm{yr}, 4.16 \mathrm{~kg} / \mathrm{m}^{2}-\mathrm{yr}$, and $31.33 \mathrm{~kg} / \mathrm{m}^{2}$-yr: The internal energy of oxygen is neglected.

Water from reaction: According to Equation (A-9), 8 mol of water are produced for each mol of algae. For the Experimental Case, Highly Productive Case II, and Idealized Case, the amount of water produced can be calculated to be $0.01 \mathrm{~kg} / \mathrm{m}^{2}-\mathrm{yr}, 0.53 \mathrm{~kg} / \mathrm{m}^{2}-\mathrm{yr}$, and $4.01 \mathrm{~kg} / \mathrm{m}^{2}$-yr. The internal energy of water was neglected.

Algal biomass: The amount of algal biomass produced in the Experimental Case, Highly Productive Case II, and Idealized Case is $0.15 \mathrm{~kg} / \mathrm{m}^{2}-\mathrm{yr}(0.26 \mathrm{~g} / \mathrm{L}), 8.93 \mathrm{~kg} / \mathrm{m}^{2}-\mathrm{yr}(1 \mathrm{~g} / \mathrm{L})$, and $67.22 \mathrm{~kg} / \mathrm{m}^{2}-\mathrm{yr}$ $(5 \mathrm{~g} / \mathrm{L})$, respectively. With an energy content of $24.49 \mathrm{MJ} / \mathrm{kg}$, these productivities are equivalent to $3.78 \mathrm{MJ} / \mathrm{m}^{2}-\mathrm{yr}, 219 \mathrm{MJ} / \mathrm{m}^{2}-\mathrm{yr}$, and $1646 \mathrm{MJ} / \mathrm{m}^{2}-\mathrm{yr}$, respectively.

\section{Photosynthetic efficiency of growth}

The photosynthetic efficiency can be calculated for each case as the energy content of the glucose produced during photosynthesis divided by the incident radiant energy. This value is different than the overall energy efficiency of growth, which includes the cost of 
living, conversion of glucose to biomass, and additional energy inputs. The energy content of glucose (per $\mathrm{m}^{2}$-d) can be calculated as,

$E D_{\mathrm{CH}_{2} \mathrm{O}}=(I \cdot \mathrm{PAR} \cdot \mathrm{PTE} \cdot \mathrm{PUE} \cdot \alpha)\left[\frac{\mathrm{MJ}}{\mathrm{m}^{2}-d}\right]$

Therefore the photosynthetic efficiency, PE, is

$\mathrm{PE}=(\mathrm{PAR} \cdot \mathrm{PTE} \cdot \mathrm{PUE} \cdot \alpha)[-]$

which can also be calculated as,

$$
\begin{aligned}
\mathrm{PE} & =\mathrm{PAR} \cdot \mathrm{PTE} \cdot \mathrm{PUE} \cdot \alpha=\frac{\hat{E}_{\mathrm{CH}_{2} \mathrm{O}}}{\hat{I}}=\frac{\hat{E}_{\mathrm{GV}}}{(1-\mathrm{COL}) \cdot \tau \cdot \dot{I}} \\
& =\frac{P_{\mathrm{GM}} \cdot \mathrm{HHV}_{\mathrm{GM}} \cdot t_{c}}{(1-\mathrm{CoL}) \cdot \tau \cdot \hat{I}}[-]
\end{aligned}
$$

where $P_{\mathrm{GM}}$ is the grown mass productivity (in $\mathrm{g} / \mathrm{L}_{\mathrm{p}}-d$ ), $\mathrm{HHV}_{\mathrm{GM}}$ is the higher heating value of grown algal biomass (in units of $\mathrm{kJ} / \mathrm{g}$ ), and $\mathrm{I}$ is the volumetric incident radiation (in units of $\mathrm{kJ} / \mathrm{L}_{\mathrm{p}}$ ). The values for each of these terms are provided above and yield photosynthetic efficiencies of 5.6 and $\mathbf{1 1 . 9}$ for the Highly Productive Case II and the Idealized Case, respectively.

\section{Growth volume temperature}

The growth model presented above assumes a large portion of the incident radiation and the mixing energy is absorbed and dissipated as heat. To evaluate the validity of this assumption, the temperature of the growth volume can be determined by estimating the heat transfer from the growth volume to the surroundings. For this analysis, the growth volume is assumed to be $0.2 \mathrm{~m}$ deep. The total heat absorbed by the growth volume (in $1 \mathrm{~m}^{2}$ per day $\left.\left(\hat{Q}_{\mathrm{abs}}\right)\right)$ is,

$$
\begin{aligned}
\grave{Q}_{\mathrm{abs}}= & \left(\grave{Q}_{\mathrm{non}-\mathrm{PAR}}+\grave{Q}_{\mathrm{non}-\mathrm{Util}}+\grave{Q}_{\mathrm{ex}}+\grave{Q}_{\text {resp }}\right. \\
& \left.+\grave{Q}_{\text {mix }}\right) \cdot \frac{1}{365}\left[\frac{\mathrm{MJ}}{\mathrm{m}^{2}-\mathrm{d}}\right]
\end{aligned}
$$

where $\grave{Q}_{\text {non-PAR }}$ is the non-photosynthetically active radiation, $\grave{Q}_{\text {non-Util }}$ is the non-utilized radiation, $\grave{Q}_{e x}$ is the excess photon energy, $Q_{\text {resp }}$ is the heat released during respiration, and $\dot{Q}_{\text {mix }}$ is the energy input for mixing (which is assumed to eventually be released as heat). These terms are calculated from the transmitted portion of the incident radiation, reported in units of $\mathrm{MJ} / \mathrm{m}^{2}-\mathrm{yr}$, and listed in Fig. 2. For the Highly Productive Case II and the Idealized Case, $Q_{\text {abs }}$ for a square meter of growth volume in one day is $17.83 \mathrm{MJ}$ and $31.82 \mathrm{MJ}$, respectively.

The growth system is modeled as receiving a constant power flux for $12 \mathrm{~h}$ per day. The growth volume is modeled with lumped capacitance, assuming a steady-state condition is reached relatively quickly each day. Additional complexity is needed to accurately model thermal conditions, however; these complexities are location-specific, season-specific, and material-specific, thereby exceeding the scope of this analysis. The heat stored and dissipated from $1 \mathrm{~m}^{2}$ of the growth volume in a day $\left(Q_{s, d}\right)$, which must equal Qabs, is,

$$
\left.Q_{s, d}=Q_{\mathrm{abs}}=Q_{\text {stored }}+Q_{\text {conv }}+Q_{\text {cond }}+Q_{\text {rad }}+Q_{\text {evap }} \quad[\mathrm{M}]\right]
$$

where $Q_{\text {stored }}$ is the heat stored in the growth volume during the day, $Q_{\text {conv }}$ is heat convection to the surrounding air; $Q_{\text {cond }}$ is heat conduction to the ground, $Q_{\text {rad }}$ is emitted radiation, and $Q_{\text {evap }}$ is the latent heat associated with water evaporation. Equation (A-19) can be expanded to be,

$$
\begin{aligned}
Q_{s, d}= & m^{\prime} A C\left(T_{w}-T_{0}\right)+\left[h A\left(T_{w}-T_{\infty}\right)+\frac{k A_{g}}{L}\left(T_{w}-T_{g}\right)\right. \\
& \left.\left.+\varepsilon A \sigma\left(T_{W}^{4}-T_{\infty}^{4}\right)+\dot{m}_{e} A h_{f g}\right] \cdot t[\mathrm{M}]\right]
\end{aligned}
$$

The terms in this equation are defined as follows: $m^{\prime}$ is the areal mass of the growth volume (200 kg per $\left.\mathrm{m}^{2}\right), C$ is the specific heat capacity (4.18 $\mathrm{kJ} / \mathrm{kg}-\mathrm{K}$ ), $T_{w}$ is the steady-state water temperature (to be determined), $T_{0}$ is the initial temperature of the water (which can be assumed to be the same as the temperature of the environment, $T_{\infty}=298 \mathrm{~K}$, due to cooling that occurs overnight), $h$ is the convection coefficient, $A$ is the upper surface area (i.e., the top), $k$ is the conductivity of the material between the growth volume and the ground, $A_{g}$ is the conduction area (i.e., the bottom), $L$ is the thickness of the material between the growth volume and the ground, $T_{g}$ is the ground temperature (which can be assumed to be $\left.T_{\infty}\right), \varepsilon$ is the emissivity, $\sigma$ is the Stephen-Boltzmann constant, $\dot{m}_{e}$ is the evaporation rate $\left(4.8 \mathrm{~kg} / \mathrm{m}^{2}-\mathrm{d}\right), h_{f g}$ is the heat of vaporization for water $(2257 \mathrm{~kJ} / \mathrm{kg}$ ), and $t$ is the time for heat transfer (i.e., $12 \mathrm{~h}$ ).

As an upper limit, the temperature of the growth volume can be calculated for an adiabatic case (in which all heat transfer from the growth volume is eliminated) by setting all of the terms inside the bracket of Equation (A-20) equal to zero. For adiabatic conditions, setting $Q_{s, d}=Q_{\mathrm{abs}}, T_{w}$ would be $317.6 \mathrm{~K}\left(112^{\circ} \mathrm{F}\right)$ and $330.8 \mathrm{~K}\left(136^{\circ} \mathrm{F}\right)$ for the Highly Productive Case II and the Idealized Case, respectively.

For a more realistic evaluation, convection can be modeled with $h=25 \mathrm{~W} / \mathrm{m}^{2}-\mathrm{K}$ and conduction can be neglected $(k \sim 0)$. The emissivity can be approximated as $\varepsilon=0.95$ and evaporation is negligible due to a closed growth environment in these cases. A typical evaporation rate for an open pond would be $\dot{m}_{e}=4.8 \mathrm{~L} / \mathrm{m}^{2}-d\left(4.8 \mathrm{~kg} / \mathrm{m}^{2}-d\right.$, which would have significant heat transfer implications). Finally, for a 12 -h period, $t=43,200 \mathrm{~s}$. Using these data and those listed below Equation (A-20), the temperature of the growth volume can be determined iteratively to be $305.5 \mathrm{~K}$ and $309.8 \mathrm{~K}$, for the Highly Productive Case II and the Idealized Case, respectively. This analysis assumes constant conditions for $12 \mathrm{~h}$ of sunlight per day, while a more thorough analysis of the growth volume temperature would need to include transient effects that occur during the day (wind, clouds, rain, etc.) and from day-to-day (seasonal effects). The specific energy and exergy flows for these cases are shown in Tables A-1 and A-2.

Table A1

Energy and exergy flows for the Highly Productive Case II.

\begin{tabular}{llll}
\hline Irradiance & 6500 & {$\left[\mathrm{MJ} / \mathrm{m}^{2}\right.$-yr $]$} & \\
Exergy-to-Energy Ratio & 0.93 & - & \\
Reflectivity & 0.05 & - & \\
Surroundings temperature & 298 & {$[\mathrm{~K}]$} & \\
Growth volume temperature & 305.523 & {$[\mathrm{~K}]$} & \\
Temperature difference & 7.523 & {$[\mathrm{~K}]$} & \\
Inputs & Energy & Daytime & Exergy \\
& {$\left[\mathrm{MJ} / \mathrm{m}^{2}\right.$-yr] } & power $\left[\mathrm{W} / \mathrm{m}^{2}\right]$ & {$[\mathrm{M}] / \mathrm{m}^{2}$-yr] } \\
Irradiance & 6500.0 & 412.2 & 6045.0 \\
Mixing & 7.2 & 0.5 & 7.2 \\
Materials & 0.0 & 0.0 & 462.0 \\
Total & 6507.2 & 412.7 & $\mathbf{6 5 1 4 . 2}$ \\
Outputs & Energy & Daytime & Exergy \\
& {$\left[\mathrm{MJ} / \mathrm{m}^{2}-\mathrm{yr}\right]$} & power $\left[\mathrm{W} / \mathrm{m}^{2}\right]$ & {$\left[\mathrm{MJ} / \mathrm{m}^{2}-\mathrm{yr}\right]$} \\
Thermal storage & 2295.6 & 145.6 & 0.0 \\
Conduction & 0.0 & 0.0 & 0.0 \\
Convection & 2965.6 & 188.1 & 0.0 \\
Growth volume & 219.0 & 13.9 & 670.0 \\
(Algal biomass) & 219.0 & 13.9 & 193.0 \\
Emission & 702.4 & 44.5 & 0.0 \\
Reflected radiation & 325.0 & 20.6 & 0.0 \\
Material outputs & 0.0 & 0.0 & 12.9 \\
(Loss) & $\mathrm{NA}$ & $\mathrm{NA}$ & 5831.3 \\
Total & 6507.5 & 412.7 & $\mathbf{6 8 2 . 9}$ \\
\hline & & &
\end{tabular}


Table A2

Energy and exergy flows for the Idealized Case.

\begin{tabular}{llll}
\hline Irradiance & 11,616 & {$\left[\mathrm{MJ} / \mathrm{m}^{2}\right.$-yr] } & \\
Exergy-to-energy ratio & 0.93 & - & \\
Reflectivity & 0.05 & - & \\
Surroundings temperature & 298 & {$[\mathrm{~K}]$} & \\
Growth volume temperature & 309.815 & {$[\mathrm{~K}]$} & \\
Temperature difference & 11.815 & {$[\mathrm{~K}]$} & \\
Input & Energy & Daytime & Exergy \\
& $\left.[\mathrm{M}] / \mathrm{m}^{2}-\mathrm{yr}\right]$ & power $\left[\mathrm{W} / \mathrm{m}^{2}\right]$ & {$\left[\mathrm{MJ} / \mathrm{m}^{2}\right.$-yr] } \\
Irradiance & $11,616.0$ & 736.7 & $10,802.9$ \\
Mixing & 0.0 & 0.0 & 0.0 \\
Materials & 0.0 & 0.0 & 462.0 \\
Total & $\mathbf{1 1 , 6 1 6 . 0}$ & $\mathbf{7 3 6 . 7}$ & $\mathbf{1 1 , 2 6 4 . 9}$ \\
Outputs & Energy & Daytime & Exergy \\
& {$\left[\mathrm{MJ} / \mathrm{m}^{2}-\mathrm{yr}\right]$} & power $\left[\mathrm{W} / \mathrm{m}^{2}\right]$ & {$\left[\mathrm{MJ} / \mathrm{m}^{2}\right.$-yr] } \\
Thermal storage & 3605.2 & 228.6 & 0.0 \\
Conduction & 0.0 & 0.0 & 0.0 \\
Convection & 4657.5 & 295.4 & 0.0 \\
Growth volume & 1646.0 & $\mathbf{1 0 4 . 4}$ & 2352 \\
(Algal biomass) & 1646.0 & $\mathbf{1 0 4 . 4}$ & 1449 \\
Emission & 1127.1 & 71.5 & 0.0 \\
Reflected radiation & 580.8 & 36.8 & 0.0 \\
Material outputs & 0.0 & 0.0 & 36.2 \\
(Loss) & $\mathrm{NA}$ & $\mathrm{NA}$ & 8876.7 \\
Total & $\mathbf{1 1 , 6 1 6 . 6}$ & $\mathbf{7 3 6 . 7}$ & $\mathbf{2 3 8 8 . 2}$ \\
\hline & & & \\
& & &
\end{tabular}

Appendix B. Standard chemical exergy and higher heating value for TAG and non-lipid biomass

The standard chemical exergy of triglyceride (TAG), $b_{c h_{\mathrm{TAC}}}^{\circ}$, is calculated as

$$
\begin{aligned}
b_{c h_{T A G}}^{\circ}= & \mathrm{HHV}-T_{0}\left[s_{\mathrm{TAG}}+n_{\mathrm{O}_{2}} \cdot s_{\mathrm{O}_{2}}-n_{\mathrm{CO}_{2}} \cdot s_{\mathrm{CO}_{2}}-n_{\mathrm{H}_{2} \mathrm{O}} \cdot s_{\mathrm{H}_{2} \mathrm{O}}\right] \\
& +n_{\mathrm{CO}_{2}} \cdot b_{\mathrm{CO}_{2}}+n_{\mathrm{H}_{2} \mathrm{O}} \cdot b_{\mathrm{H}_{2} \mathrm{O}}-n_{\mathrm{O}_{2}} \cdot b_{\mathrm{O}_{2}}
\end{aligned}
$$

for the following reaction,

$$
\mathrm{C}_{57} \mathrm{H}_{104} \mathrm{O}_{6}+80 \mathrm{O}_{2} \rightarrow 57 \mathrm{CO}_{2}+52 \mathrm{H}_{2} \mathrm{O}
$$

and was determined to be $35.13 \mathrm{MJ} / \mathrm{mol}(39.7 \mathrm{MJ} / \mathrm{kg}$ ). Standard entropy values and standard chemical exergy values used to evaluate Equation (B-1) were obtained from reference materials [13,27] and $39.6 \mathrm{MJ} / \mathrm{kg}$ was used as the HHV of triglyceride [38]. The entropy of TAG was estimated to be $1169 \mathrm{~kJ} / \mathrm{mol}-\mathrm{K}$ according to the data presented by Battley [21]. Similarly, the standard chemical exergy for non-lipid biomass (BM), $b_{c h_{\mathrm{BM}}^{\circ}}$, can be determined from,

$$
\begin{aligned}
b_{c h_{\mathrm{BM}}}^{\circ}= & \text { HHV }-T_{0}\left[s_{\mathrm{BS}}+n_{\mathrm{O}_{2}} \cdot s_{\mathrm{O}_{2}}-n_{\mathrm{CO}_{2}} \cdot s_{\mathrm{CO}_{2}}-n_{\mathrm{H}_{2} \mathrm{O}} \cdot s_{\mathrm{H}_{2} \mathrm{O}}\right. \\
& \left.-n_{\mathrm{N}_{2}} \cdot s_{\mathrm{N}_{2}}-n_{\mathrm{P}_{2} \mathrm{O}_{5}} \cdot s_{\mathrm{P}_{2} \mathrm{O}_{5}}\right]+n_{\mathrm{CO}_{2}} \cdot b_{\mathrm{CO}_{2}}+n_{\mathrm{H}_{2} \mathrm{O}} \cdot b_{\mathrm{H}_{2} \mathrm{O}} \\
& +n_{\mathrm{N}_{2}} \cdot b_{\mathrm{N}_{2}}+n_{\mathrm{P}_{2} \mathrm{O}_{5}} \cdot b_{\mathrm{P}_{2} \mathrm{O}_{5}}-n_{\mathrm{O}_{2}} \cdot b_{\mathrm{O}_{2}}
\end{aligned}
$$

for the following reaction,

$\mathrm{CH}_{w} \mathrm{O}_{x} \mathrm{~N}_{y} \mathrm{P}_{z}+a \mathrm{O}_{2} \rightarrow \mathrm{CO}_{2}+\left(\frac{y}{2}\right) \mathrm{N}_{2}+\left(\frac{w}{2}\right) \mathrm{H}_{2} \mathrm{O}+\left(\frac{z}{2}\right) \mathrm{P}_{2} \mathrm{O}_{5}$ where $w, x, y$, and $z$ are defined above (cf. Section 2.5.2) and $a$ is 2.45 for the Experimental Case and 0.75 for the Highly Productive Case II and Idealized Case. The HHV for the non-lipid biomass, $\mathrm{HHV}_{\mathrm{BM}}$, can be determined according to,

$$
\mathrm{HHV}_{\text {algae }}=24.49=X_{\mathrm{TAG}}(39.6)+X_{\mathrm{BM}}\left(\mathrm{HHV}_{\mathrm{BM}}\right) \quad \mathrm{MJ} / \mathrm{kg}
$$

where $X_{\text {TAG }}$ is the TAG fraction (0.018 for Experimental Case and 0.50 for Highly Productive Case II and Idealized Case). Therefore, the $\mathrm{HHV}_{\mathrm{BM}}$ is $24.21 \mathrm{MJ} / \mathrm{kg}$ for the Experimental Case and $9.26 \mathrm{MJ} / \mathrm{kg}$ for the Highly Productive Case II and Idealized Case. These results agree well with the results calculated from Equation (A-12) (cf. Appendix A), which are $24.19 \mathrm{MJ} / \mathrm{kg}$ and $9.26 \mathrm{MJ} / \mathrm{kg}$, respectively. Using these relations, the standard chemical exergy for non-lipid biomass is $569.82 \mathrm{~kJ} / \mathrm{mol}$ for the Experimental Case and $440.73 \mathrm{~kJ} / \mathrm{mol}$ for the Highly Productive Case II and Idealized Case.

\section{Appendix C. Entropy and exergy calculation tables}

The symbols for the data presented in the following tables are:

Algal concentration $(\mathrm{g} / \mathrm{L})-\mu$

Algae concentration $(\mathrm{mol} / \mathrm{kL})-n_{\text {algae }}$

Mass of algae per $k \mathrm{~L}_{\mathrm{p}}(\mathrm{g} / \mathrm{kL} \mathrm{p})-\dot{M}$

The standard chemical exergy of algae $(\mathrm{kJ} / \mathrm{mol})-b_{c}^{\circ}$

The standard partial molar entropy of algae $(\mathrm{J} / \mathrm{mol}-\mathrm{K})-\tilde{s}_{\text {algae }}^{\circ}$

Water concentration $(\mathrm{g} / \mathrm{L}$ or $\mathrm{mol} / \mathrm{kL})-n_{\text {water }}$

The standard chemical exergy water $(\mathrm{kJ} / \mathrm{mol})-b_{c h}^{\circ}$

The standard partial molar entropy of water $(\mathrm{J} / \mathrm{mol}-\mathrm{K})-\tilde{s}_{\text {water }}^{\circ}$

TAG concentration $(\mathrm{mol} / \mathrm{kL})$ - ń $\mathrm{TAG}$

The standard chemical exergy of TAG $(\mathrm{kJ} / \mathrm{mol})-b_{c h}^{\circ}$

The standard partial molar entropy of TAG $(\mathrm{J} / \mathrm{mol}-\mathrm{K})-\tilde{s}_{\mathrm{TAC}}$

BM (non-lipid biomass in slurry) concentration (mol/kL) - $n_{\mathrm{BM}}$

The standard chemical exergy of BM $(\mathrm{kJ} / \mathrm{mol})-b^{\circ}$

The standard partial molar entropy of $\mathrm{BM}(\mathrm{J} / \mathrm{mol}-\mathrm{K})-\tilde{s}_{B M}^{\circ}$

$\mathrm{BC}$ concentration $(\mathrm{mol} / \mathrm{kL})-\dot{n}_{\mathrm{BC}}$

$B C$ mass per $k L$ processed $\left(g / L_{p}\right)$ - no symbol.

The standard chemical exery of BC (same as TAG) $(\mathrm{kJ} / \mathrm{mol})-$ $b_{C l_{\text {BC }}}^{\circ}$

The standard partial molar entropy of BC (same as TAG) (J/ mol-K) $-\tilde{s}_{\mathrm{BC}}^{\circ}$

Volume of $B C$ per $L$ processed $\left(L / L_{p}\right)$ - no symbol.

Total moles (moles) - no symbol.

Entropy of mixing $(\mathrm{kJ} / \mathrm{L}-\mathrm{K})$ - no symbol entropy of intermediate product solution $(\mathrm{kJ} / \mathrm{L}-\mathrm{K})-S^{\circ}$

Entropy of intermediate product solution per kL processed $\left(\mathrm{kJ} / \mathrm{L}_{\mathrm{p}}-\mathrm{K}\right)-\hat{S}^{\circ}$

\begin{tabular}{|c|c|c|c|c|c|c|c|c|c|c|c|c|c|}
\hline $\begin{array}{l}\text { Algae } \\
\text { conc. } \\
\text { (g/L) }\end{array}$ & $\begin{array}{l}\text { Mass algae } \\
\text { per } k L \text { proc. } \\
\left(\mathrm{g} / \mathrm{kL}_{\mathrm{p}}\right)\end{array}$ & $\begin{array}{l}\text { Algae conc. } \\
\text { (mol/kL) }\end{array}$ & $\begin{array}{l}\text { Chem } \\
\text { exergy } \\
\text { algae } \\
(\mathrm{kJ} / \mathrm{mol})\end{array}$ & $\begin{array}{l}\text { Water } \\
\text { conc. } \\
(\mathrm{g} / \mathrm{L})\end{array}$ & $\begin{array}{l}\text { Water conc. } \\
(\mathrm{mol} / \mathrm{kL})\end{array}$ & $\begin{array}{l}\text { Chem } \\
\text { exergy } \\
\text { water } \\
(\mathrm{kJ} / \mathrm{mol})\end{array}$ & $\begin{array}{l}\text { Total mols } \\
(\mathrm{mol} / \mathrm{kL})\end{array}$ & $\begin{array}{l}\text { Partial molar } \\
\text { entropy algae } \\
(\mathrm{J} / \mathrm{mol}-\mathrm{K})\end{array}$ & $\begin{array}{l}\text { Partial molar } \\
\text { entropy water } \\
(\mathrm{J} / \mathrm{mol}-\mathrm{K})\end{array}$ & $\begin{array}{l}\text { Entropy mixing } \\
\text { water, algae } \\
\text { (Sgen) (kJ/L-K) }\end{array}$ & $\begin{array}{l}\text { Entropy of } \\
\text { growth vol. } \\
\text { per kL Proc. } \\
\left(\mathrm{kJ} / \mathrm{L}_{\mathrm{p}}-\mathrm{K}\right)\end{array}$ & $\begin{array}{l}\text { Exergy } \\
(\mathrm{MJ} / \mathrm{kL})\end{array}$ & $\begin{array}{l}\text { Exergy per } \\
\mathrm{kL} \text { of } \mathrm{GV} \\
\left(\mathrm{MJ} / \mathrm{kL}_{\mathrm{p}}\right)\end{array}$ \\
\hline 0.26 & 260 & 0.11 & $60,477.91$ & 999.74 & $55,541.11$ & 0.90 & $55,541.22$ & 3289.36 & 69.92 & 0.00 & 3.88 & 56.50 & 56.50 \\
\hline 1 & 1000 & 0.41 & $60,477.91$ & 999.00 & $55,500.00$ & 0.90 & $55,500.41$ & 3278.15 & 69.92 & 0.00 & 3.88 & 74.99 & 74.99 \\
\hline 5 & 5000 & 2.07 & $60,477.91$ & 995.00 & $55,279.78$ & 0.90 & $55,279.85$ & 3264.74 & 69.92 & 0.00 & 3.87 & 174.96 & 174.96 \\
\hline
\end{tabular}

Exergy of intermediate product solution $(\mathrm{MJ} / \mathrm{kL})-B_{c h}$

Exergy of intermediate product solution per kL processed $\left(\mathrm{MJ} / \mathrm{kL}_{\mathrm{p}}\right)-\dot{B}_{c l l}$.

Table C1

Entropy and exergy calculations for the growth volume of the Experimental Case, Highly Productive Case II, and Idealized Case (shown on the top, middle, and bottom row, respectively). All of the growth volume is processed. 
Table C2

Entropy and exergy calculations for the algal concentrate of the Experimental Case, Highly Productive Case II, and Idealized Case (shown on the first, second, and third row, respectively). Rows 4 and 5 are provided for future calculations.

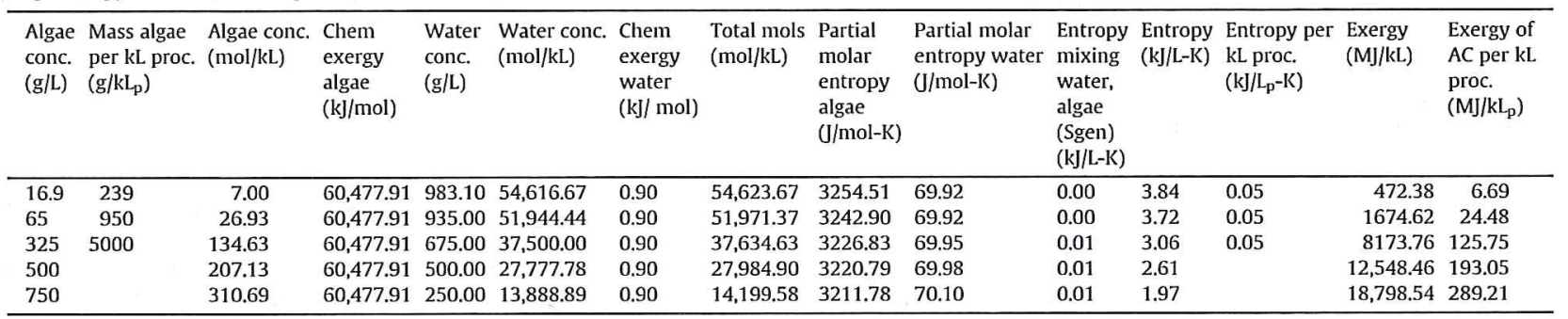

Table C3

Entropy and exergy calculations for the discharge water of the Experimental Case, Highly Productive Case II, and Idealized Case (shown on the first, second, and third row, respectively).

\begin{tabular}{|c|c|c|c|c|c|c|c|c|c|c|c|c|c|}
\hline $\begin{array}{l}\text { Algae } \\
\text { conc. } \\
(\mathrm{g} / \mathrm{L})\end{array}$ & $\begin{array}{l}\text { Mass algae } \\
\text { per kL proc. } \\
\left(\mathrm{g} / \mathrm{kL}_{\mathrm{p}}\right)\end{array}$ & $\begin{array}{l}\text { Algae conc. } \\
(\mathrm{mol} / \mathrm{kL})\end{array}$ & $\begin{array}{l}\text { Chem } \\
\text { exergy } \\
\text { algae } \\
(\mathrm{kJ} / \mathrm{mol})\end{array}$ & $\begin{array}{l}\text { Water } \\
\text { conc. } \\
\text { (g/L) }\end{array}$ & $\begin{array}{l}\text { Water conc. } \\
(\mathrm{mol} / \mathrm{kL})\end{array}$ & $\begin{array}{l}\text { Chem } \\
\text { exergy } \\
\text { water } \\
(\mathrm{kJ} / \mathrm{mol})\end{array}$ & $\begin{array}{l}\text { Total mols } \\
(\mathrm{mol} / \mathrm{kL})\end{array}$ & $\begin{array}{l}\text { Partial molar } \\
\text { entropy algae } \\
(\mathrm{J} / \mathrm{mol}-\mathrm{K})\end{array}$ & $\begin{array}{l}\text { Partial molar } \\
\text { entropy water } \\
(\mathrm{J} / \mathrm{mol}-\mathrm{K})\end{array}$ & $\begin{array}{l}\text { Entropy } \\
(\mathrm{kJ} / \mathrm{L}-\mathrm{K})\end{array}$ & $\begin{array}{l}\text { Entropy per } \\
\mathrm{kL} \text { proc. } \\
\left(\mathrm{kJ} / \mathrm{L}_{\mathrm{p}}-\mathrm{K}\right)\end{array}$ & $\begin{array}{l}\text { Exergy } \\
(\mathrm{MJ} / \mathrm{kL})\end{array}$ & $\begin{array}{l}\text { Exergy of } \\
\text { DW per kL } \\
\text { proc. } \\
\left(\mathrm{MJ} / \mathrm{kL}_{\mathrm{p}}\right)\end{array}$ \\
\hline 0.02 & 20.80 & 0.01 & $60,477.9$ & 999.98 & $55,554.38$ & 0.90 & $55,554.39$ & 3310.24 & 69.92 & 3.88 & 3.83 & 50.53 & 49.81 \\
\hline 0.05 & 50.00 & 0.02 & $60,477.9$ & 999.95 & $55,552.74$ & 0.90 & $55,552.76$ & 3302.94 & 69.92 & 3.88 & 3.83 & 51.27 & 50.52 \\
\hline 0.00 & 0.00 & 0.00 & $60,477.9$ & 1000.00 & $55,555.56$ & 0.90 & $55,555.56$ & 0.00 & 69.92 & 3.88 & 3.82 & 50.00 & 49.23 \\
\hline
\end{tabular}

Table C4

Entropy and exergy calculations for the lysed concentrate of the Experimental Case, Highly Productive Case II, and Idealized Case (shown on the first, second, and third row, respectively).

\begin{tabular}{|c|c|c|c|c|c|c|c|c|c|c|c|c|c|c|c|}
\hline $\begin{array}{l}\text { Algae } \\
\text { conc. } \\
\text { (g/L) }\end{array}$ & $\begin{array}{l}\text { Mass algae } \\
\text { per } \mathrm{kL} \text { proc. } \\
\left(\mathrm{g} / \mathrm{kL}_{\mathrm{p}}\right)\end{array}$ & $\begin{array}{l}\text { TAG conc. } \\
(\mathrm{mol} / \mathrm{kL})\end{array}$ & $\begin{array}{l}\text { Chem } \\
\text { exergy } \\
\text { TAG (MJ/ } \\
\text { mol) }\end{array}$ & $\begin{array}{l}\text { BM conc. } \\
\text { (kmol/kL) }\end{array}$ & $\begin{array}{l}\text { Chem } \\
\text { exergy } \\
\text { BM (kJ) } \\
\text { mol) }\end{array}$ & $\begin{array}{l}\text { Water } \\
\text { conc. } \\
\text { (kmol/ } \\
\text { kL) }\end{array}$ & $\begin{array}{l}\text { Chem } \\
\text { exergy } \\
\text { water } \\
(\mathrm{kJ} / \mathrm{mol})\end{array}$ & $\begin{array}{l}\text { Total } \\
\text { kmols }\end{array}$ & $\begin{array}{l}\text { Partial molar } \\
\text { entropy TAG } \\
(\mathrm{kJ} / \mathrm{mol}-\mathrm{K})\end{array}$ & $\begin{array}{l}\text { Partial molar } \\
\text { entropy BM } \\
(\mathrm{J} / \mathrm{mol}-\mathrm{K})\end{array}$ & $\begin{array}{l}\text { Partial molar } \\
\text { entropy } \mathrm{H}_{2} \mathrm{O} \\
(\mathrm{J} / \mathrm{mol}-\mathrm{K})\end{array}$ & $\begin{array}{l}\text { Entr. } \\
\text { LC sol. } \\
\text { (kJ/L-K) }\end{array}$ & $\begin{array}{l}\text { Entr. of } L C \\
\text { per } L \text { Proc. } \\
\left(k J / L_{p}-K\right)\end{array}$ & $\begin{array}{l}\text { Exergy of } \\
\mathrm{LC}(\mathrm{MJ} / \mathrm{kL})\end{array}$ & $\begin{array}{l}\text { Exergy of } \\
\mathrm{LC} \text { per kL } \\
\text { proc. }(\mathrm{MJ} / \\
\left.\mathrm{kL}_{\mathrm{p}}\right)\end{array}$ \\
\hline 65 & 940.50 & 36.62 & 35.13 & 0.76 & 440.73 & 51.94 & 0.90 & 52.74 & 1.23 & 93.04 & 70.05 & 3.75 & 0.06 & 1658.24 & 23.99 \\
\hline 325 & 5000 & 183.10 & 35.13 & 3.81 & 440.73 & 37.50 & 0.90 & 41.49 & 1.21 & 77.66 & 70.76 & 3.17 & 0.06 & 8109.89 & 124.77 \\
\hline 500 & & 281.69 & 35.13 & 5.86 & 440.73 & 27.78 & 0.90 & 33.92 & 1.21 & 72.41 & 71.58 & 2.75 & & $12,460.17$ & \\
\hline 750 & & 422.54 & 35.13 & 8.79 & 440.73 & 13.89 & 0.90 & 23.10 & 1.20 & 65.84 & 74.14 & 2.12 & & $18,686.40$ & \\
\hline
\end{tabular}

Table C5

Entropy and exergy calculations for the lysing loss of the Experimental Case, Highly Productive Case II, and Idealized Case (shown on the first, second, and third row, respectively).

\begin{tabular}{|c|c|c|c|c|c|c|c|c|c|c|c|c|c|c|c|}
\hline $\begin{array}{l}\text { Algae } \\
\text { conc. } \\
\text { (g/L) }\end{array}$ & $\begin{array}{l}\text { Mass algae } \\
\text { per kL } \\
\text { proc. } \\
\left(\mathrm{g} / \mathrm{kL}_{\mathrm{p}}\right)\end{array}$ & $\begin{array}{l}\text { TAG conc. } \\
\text { (mol/kL) }\end{array}$ & $\begin{array}{l}\text { Chem } \\
\text { exergy } \\
\text { TAG (MJ/ } \\
\text { mol) }\end{array}$ & $\begin{array}{l}\text { BM conc. } \\
\text { (kmol/kL) }\end{array}$ & $\begin{array}{l}\text { Chem } \\
\text { exergy } \\
\text { BM (kJ/ } \\
\text { mol) }\end{array}$ & $\begin{array}{l}\text { Water } \\
\text { conc. } \\
\text { (kmol/ } \\
\text { kL) }\end{array}$ & $\begin{array}{l}\text { Chem } \\
\text { exergy } \\
\text { water } \\
(\mathrm{kJ} / \mathrm{mol})\end{array}$ & $\begin{array}{l}\text { Total } \\
\text { kmols }\end{array}$ & $\begin{array}{l}\text { Partial } \\
\text { molar } \\
\text { entropy } \\
\text { TAG }(\mathrm{kJ} / \\
\text { mol-K) }\end{array}$ & $\begin{array}{l}\text { Partial } \\
\text { molar } \\
\text { entropy } \\
\text { BM (J/ } \\
\text { mol-K) }\end{array}$ & $\begin{array}{l}\text { Partial } \\
\text { molar } \\
\text { entropy } \\
\mathrm{H}_{2} \mathrm{O}(\mathrm{J} / \\
\text { mol-K) }\end{array}$ & $\begin{array}{l}\text { Entr. LL sol. } \\
\text { (kJ/L-K) }\end{array}$ & $\begin{array}{l}\text { Entr. of } L L \\
\text { per } L \text { Proc. } \\
\left(k J / L_{p}-K\right)\end{array}$ & $\begin{array}{l}\text { Exergy of } \\
\mathrm{LL}(\mathrm{MJ} / \mathrm{kL})\end{array}$ & $\begin{array}{l}\text { Exergy of } \\
\text { LL per kL } \\
\text { Proc. } \\
\left(\mathrm{MJ} / \mathrm{kL}_{\mathrm{p}}\right)\end{array}$ \\
\hline 16.9 & 19.14 & 0.21 & 35.13 & 0.73 & 569.82 & 54.62 & 0.90 & 55.34 & 1.27 & 66.07 & 70.03 & 3.87 & 0.00 & 463.38 & 0.52 \\
\hline 65 & 9.50 & 36.62 & 35.13 & 0.76 & 440.73 & 51.93 & 0.90 & 52.74 & 1.23 & 93.04 & 70.05 & 3.75 & 0.00 & 1658.2 & 0.24 \\
\hline 325 & 0.00 & 183.10 & 35.13 & 3.81 & 440.73 & 37.50 & 0.90 & 41.49 & 1.21 & 77.66 & 70.76 & 3.17 & 0.00 & 8109.9 & 0.00 \\
\hline
\end{tabular}

Table C6

Entropy and exergy calculations for the post-extraction biomass in slurry of the Experimental Case, Highly Productive Case II, and Idealized Case (shown on the first, second, and third row, respectively).

\begin{tabular}{|c|c|c|c|c|c|c|c|c|c|c|c|c|}
\hline $\begin{array}{l}\text { Algae conc. } \\
(\mathrm{g} / \mathrm{L})\end{array}$ & $\begin{array}{l}\text { Mass algae } \\
\text { per kL proc. } \\
\left(g / \mathrm{kL}_{\mathrm{p}}\right)\end{array}$ & $\begin{array}{l}\text { BM conc. } \\
(\mathrm{mol} / \mathrm{kL})\end{array}$ & $\begin{array}{l}\text { Chem } \\
\text { exergy } \\
\text { BM (kJ/ } \\
\text { mol) }\end{array}$ & $\begin{array}{l}\text { Water } \\
\text { conc. } \\
(\mathrm{mol} / \mathrm{kL})\end{array}$ & $\begin{array}{l}\text { Chem } \\
\text { exergy } \\
\text { water } \\
(\mathrm{kJ} / \mathrm{mol})\end{array}$ & Total mols & $\begin{array}{l}\text { Partial molar } \\
\text { entropy BM } \\
(\mathrm{J} / \mathrm{mol}-\mathrm{K})\end{array}$ & $\begin{array}{l}\text { Partial molar } \\
\text { entropy } \mathrm{H}_{2} \mathrm{O} \\
(\mathrm{J} / \mathrm{mol}-\mathrm{K})\end{array}$ & $\begin{array}{l}\text { Entropy of } \\
\text { BS (kJ/L-K) }\end{array}$ & $\begin{array}{l}\text { Entropy of BS } \\
\text { per L proc. } \\
\left(\mathrm{kJ} / \mathrm{L}_{\mathrm{p}}-\mathrm{K}\right)\end{array}$ & $\begin{array}{l}\text { Exergy of } \\
\mathrm{BS}(\mathrm{MJ} / \mathrm{kL})\end{array}$ & $\begin{array}{l}\text { Exergy of BS } \\
\text { per kL proc. } \\
\left(\mathrm{MJ} / \mathrm{kL}_{\mathrm{p}}\right)\end{array}$ \\
\hline 16.6 & 165.00 & 725.02 & 569.82 & $54,616.67$ & 0.90 & $55,341.69$ & 66.04 & 70.03 & 3.87 & 0.04 & 452.72 & 4.50 \\
\hline 32.5 & 470.25 & 758.64 & 440.73 & $51,944.44$ & 0.90 & $52,703.08$ & 93.07 & 70.04 & 3.71 & 0.03 & 371.26 & 5.37 \\
\hline 162.5 & 2500.00 & 3793.18 & 440.73 & $37,500.00$ & 0.90 & $41,293.18$ & 77.66 & 70.72 & 2.95 & 0.02 & 1674.12 & 25.76 \\
\hline
\end{tabular}


Table C7

Entropy and exergy calculations for the post-extraction biomass in slurry loss of the Experimental Case, Highly Productive Case II, and Idealized Case (shown on the first, second, and third row, respectively).

\begin{tabular}{|c|c|c|c|c|c|c|c|c|c|c|c|c|}
\hline $\begin{array}{l}\text { Algae } \\
\text { conc. } \\
(\mathrm{g} / \mathrm{L})\end{array}$ & $\begin{array}{l}\text { Mass algae } \\
\text { per kL proc. } \\
\left(\mathrm{g} / \mathrm{kL}_{\mathrm{p}}\right)\end{array}$ & $\begin{array}{l}\text { BM conc. } \\
\text { (mol/kL) }\end{array}$ & $\begin{array}{l}\text { Chem exergy } \\
\mathrm{BM}(\mathrm{kJ} / \mathrm{mol})\end{array}$ & $\begin{array}{l}\text { Water } \\
\text { conc. } \\
(\mathrm{mol} / \mathrm{kL})\end{array}$ & $\begin{array}{l}\text { Chem exergy } \\
\text { water }(\mathrm{kJ} / \mathrm{mol})\end{array}$ & Total mols & $\begin{array}{l}\text { Partial molar } \\
\text { entropy BM } \\
(\mathrm{J} / \mathrm{mol}-\mathrm{K})\end{array}$ & $\begin{array}{l}\text { Partial molar } \\
\text { entropy } \mathrm{H}_{2} \mathrm{O} \\
(\mathrm{J} / \mathrm{mol}-\mathrm{K})\end{array}$ & $\begin{array}{l}\text { Entropy of } \\
\text { BSL (kJ/L-K) }\end{array}$ & $\begin{array}{l}\text { Entropy of } \\
\text { BSL }\left(\mathrm{kJ} / \mathrm{L}_{\mathrm{p}}-\mathrm{K}\right)\end{array}$ & $\begin{array}{l}\text { Exergy of } \\
\text { BSL (MJ/kL) }\end{array}$ & $\begin{array}{l}\text { Exergy of BSL } \\
\text { per kL proc. } \\
\left(\mathrm{MJ} / \mathrm{kL}_{\mathrm{p}}\right)\end{array}$ \\
\hline 16.6 & 51.11 & 725.02 & 569.82 & $54,616.67$ & 0.90 & $55,341.69$ & 66.04 & 70.03 & 3.87 & 0.01 & 452.72 & 1.39 \\
\hline 65 & 0 & 0 & 0 & 0 & 0 & 0 & 0 & 0 & 0 & 0 & 0 & 0 \\
\hline 325 & 0 & 0 & 0 & 0 & 0 & 0 & 0 & 0 & 0 & 0 & 0 & 0 \\
\hline
\end{tabular}

Table C8

Entropy and exergy calculations for the biocrude (assumed to be triglyceride) of the Experimental Case, Highly Productive Case II, and Idealized Case (shown on the first, second, and third row, respectively).

\begin{tabular}{|c|c|c|c|c|c|c|c|c|c|}
\hline $\begin{array}{l}\text { Density } \\
(\mathrm{g} / \mathrm{mL})\end{array}$ & $\begin{array}{l}\text { BC per kL } \\
\text { Proc. }\left(g / k L_{p}\right)\end{array}$ & $\begin{array}{l}\text { Chem exergy } \\
\mathrm{BC}(\mathrm{kJ} / \mathrm{mol})\end{array}$ & $\begin{array}{l}\text { Abs. entropy } \\
(\mathrm{kJ} / \mathrm{L}-\mathrm{K})\end{array}$ & $\begin{array}{l}\text { Vol. BC/Vol. } \\
\text { proc. }\left(L / L_{p}\right)\end{array}$ & $\begin{array}{l}\text { BC conc. } \\
(\mathrm{mol} / \mathrm{kL})\end{array}$ & $\begin{array}{l}\text { Entropy of } \\
B C(\mathrm{~kJ} / \mathrm{L}-\mathrm{K})\end{array}$ & $\begin{array}{l}\text { Entropy of } \\
\text { BC per L proc. } \\
\left(\mathrm{kJ} / \mathrm{L}_{\mathrm{p}}-\mathrm{K}\right)\end{array}$ & $\begin{array}{l}\text { Exergy of } \\
B C(M J / k L)\end{array}$ & $\begin{array}{l}\text { Exergy of } B C \\
\text { per kL proc. } \\
\left(\mathrm{MJ} / \mathrm{kL}_{\mathrm{p}}\right)\end{array}$ \\
\hline 0.9 & 3.57 & 35,125 & 1.17 & $3.96 \mathrm{E}-06$ & 1016.95 & 1.19 & $4.71 \mathrm{E}-06$ & $35,720.40$ & 0.14 \\
\hline 0.9 & 423.23 & 35,125 & 1.17 & $4.70 \mathrm{E}-4$ & 1016.95 & 1.19 & $5.59 \mathrm{E}-04$ & $35,720.40$ & 16.80 \\
\hline 0.9 & 2500.00 & 35,125 & 1.17 & 2.78E-03 & 1016.95 & 1.19 & $3.30 \mathrm{E}-03$ & $35,720.40$ & 99.22 \\
\hline
\end{tabular}

Table c9

Entropy and exergy calculations for the biocrude loss (assumed to be triglyceride) of the Experimental Case, Highly Productive Case II, and Idealized Case (shown on the first, second, and third row, respectively).

\begin{tabular}{|c|c|c|c|c|c|c|c|c|c|}
\hline $\begin{array}{l}\text { Density } \\
(\mathrm{g} / \mathrm{mL})\end{array}$ & $\begin{array}{l}\text { BC Loss per } \\
\text { kL. Proc. } \\
\left(\mathrm{g} / \mathrm{kL}_{\mathrm{p}}\right)\end{array}$ & $\begin{array}{l}\text { Chem exergy } \\
\mathrm{BC}(\mathrm{kJ} / \mathrm{mol})\end{array}$ & $\begin{array}{l}\text { Abs. entropy } \\
\text { (kJ/L-K) }\end{array}$ & $\begin{array}{l}\text { Vol. } B C / \text { Vol. } \\
\text { proc. }\left(L / L_{p}\right)\end{array}$ & $\begin{array}{l}\text { BC conc. } \\
(\mathrm{mol} / \mathrm{kL})\end{array}$ & $\begin{array}{l}\text { Entropy of BC } \\
(\mathrm{kJ} / \mathrm{L}-\mathrm{K})\end{array}$ & $\begin{array}{l}\text { Entropy of } \\
\text { BC per } \mathrm{L} \text { proc. } \\
\left(\mathrm{kJ} / \mathrm{L}_{\mathrm{p}}-\mathrm{K}\right)\end{array}$ & $\begin{array}{l}\text { Exergy of } B C \\
(\mathrm{MJ} / \mathrm{kL})\end{array}$ & $\begin{array}{l}\text { Exergy of } B C \text { per kL } \\
\text { proc. }\left(M J / k L_{p}\right)\end{array}$ \\
\hline 0.9 & 0.40 & 35,125 & 1.17 & $4.40 \mathrm{E}-07$ & 1016.95 & 1.19 & $5.23 \mathrm{E}-07$ & $35,720.40$ & 0.02 \\
\hline 0.9 & 0.00 & 35,125 & 1.17 & 0.00 & 1016.95 & 1.19 & $0.00 \mathrm{E}+00$ & $35,720.40$ & 0.00 \\
\hline
\end{tabular}

\section{References}

[1] Beal CM, Hebner RE, Webber ME, Ruoff RS, Seibert AF. The energy return on investment for algal biocrude: results for a research production facility. BioEnergy Research; 2011:1-22.

[2] Pate R, Klise G, Wu B. Resource demand implications for US algae biofuels production scale-up. Applied Energy 2011;88(10):3377-88.

[3] Sun A, Davis R, Starbuck M, Ben-Amotz A, Pate R, Pienkos PT. Comparative cost analysis of algal oil production for biofuels. Energy 2011;36(8):5169-79.

[4] Davis R, Aden A, Pienkos PT. Techno-economic analysis of autotrophic microalgae for fuel production. Applied Energy 2011;88(10):3524-31.

[5] Beal CM. Constraints on algal biofuel production. Austin TX. http:// repositories.lib.utexas.edu/handle/2152/ETD-UT-2011-05-2775: Doctoral Dissertation, University of Texas at Austin, 2011.

[6] Lundquist TJ, Woertz IC, Quinn NWT, Benemann JR. A realistic technology and engineering assessment of algae biofuel production. Energy Biosciences Institute, University of California; 2010.

[7] Robertson D, Jacobson S, Morgan F, Berry D, Church G, Afeyan N. A new dawn for industrial photosynthesis. Photosynthesis Research 2011;107(3):269-77.

[8] Weyer K, Bush D, Darzins A, Willson B. Theoretical maximum algal oil production. BioEnergy Research 2010;3(2):204-13.

[9] Dewulf J, Van Langenhove H, Van De Velde B. Exergy-based efficiency and renewability assessment of biofuel production. Environmental Science \& Technology 2005:39(10):3878-82.

[10] Sorguven E, Ozilgen $M$. Thermodynamic assessment of algal biodiesel utilization. Renewable Energy 2010;35(9):1956-66.

[11] Peralta Y, Sanchez E, Kafarov V. Exergy analysis for third generation biofuel production from microalgae biomass. Chemical Engineering Transactions; 2010:21.

[12] Kucukvar M, Tatari $O$. A comprehensive life cycle analysis of cofiring algae in a coal power plant as a solution for achieving sustainable energy. Energy 2011;36(11):6352-7.

[13] Cengel YA, Boles MA. Thermodynamics: an engineering approach. 5th ed. New York, NY: McGraw Hill; 2006.

[14] Myers AL, Prausnitz JM. Thermodynamics of mixed-gas adsorption. AIChE Journal 1965;11(1):121-7.

[15] Szargut J, Morris DR, Steward FR. Energy analysis of thermal, chemical, and metallurgical processes,; 1988.

[16] Badescu V. Maximum conversion efficiency for the utilization of multiply scattered solar radiation. Journal of Physics D: Applied Physics 1991;24(10): 1882.
[17] Beal CM, Smith CH, Webber ME, Ruoff RS, Hebner RE. A framework to report the production of renewable diesel from algae. BioEnergy Research 2011;4(1): 36-60.

[18] Mulder K, Hagens NJ. Energy return on investment: toward a consistent framework. AMBIO: A Journal of the Human Environment 2009;37(2): 74-9.

[19] Clarens AF, Resurreccion EP, White MA, Colosi LM. Environmental life cycle comparison of algae to other bioenergy feedstocks. Environmental Science \& Technology 2010;44(5):1813-9.

[20] Scott SA, Davey MP, Dennis JS, Horst I, Howe CJ, Lea-Smith DJ, et al. Biodiesel from algae: challenges and prospects. Current Opinion in Biotechnology 2010; 21(3):277-86.

[21] Battley EH. An empirical method for estimating the entropy of formation and the absolute entropy of dried microbial biomass for use in studies on the thermodynamics of microbial growth. Thermochimica Acta 1999;326(1-2): $7-15$.

[22] Ikumi S, Luo CD, Wen CY. A method of estimating entropies of coal and coal liquids. Canadian Journal of Chemical Engineering; 1982:60.

23] Candau Y. On the exergy of radiation. Solar Energy 2003;75(3):241-7.

[24] Petela R. Exergy of undiluted thermal radiation. Solar Energy 2003;74(6): 469-88.

[25] Petela R. An approach to the exergy analysis of photosynthesis. Solar Energy 2008;82(4):311-28.

[26] Badescu V. Accurate upper bound for the efficiency of converting solar energy into work. Journal of Physics D: Applied Physics 1998;31(7):820.

[27] Moran MJ, Shapiro HN. Fundamentals of engineering thermodynamics. 4th ed. New York, NY: John Wiley \& Sons Inc; 2000.

[28] Lu Y, Guo L, Zhang X, Yan Q. Thermodynamic modeling and analysis of biomass gasification for hydrogen production in supercritical water. Chemical Engineering Journal 2007;131:233-44.

[29] Ugwu CU, Aoyagi H, Uchiyama H. Photobioreactors for mass cultivation of algae. Bioresource Technology 2008;99(10):4021-8.

[30] Beal CM, Hebner RE, Romanovicz D, Mayer CC, Connelly R. Progression of lipid Profile and cell structure in a research production pathway for algal biocrude. Renewable energy. Accepted.

[31] Chang DC. Cell poration and cell fusion using an oscillating electric field. Biophysical Journal 1989;56(4):641-52.

[32] Pliquett U, Joshi RP, Sridhara V, Schoenbach KH. High electrical field effects on cell membranes. Bioelectrochemistry 2007;70(2):275-82.

[33] Teissie J, Golzio M, Rols MP. Mechanisms of cell membrane electropermeabilization: a minireview of our present (lack of ?) knowledge. 
Biochimica et Biophysica Acta (BBA) - General Subjects 2005;1724(3): $270-80$.

[34] Vlahovska PM, Ales I. Nonequilibrium dynamics of lipid membranes: deformation and stability in electric fields. Advances in planar lipid bilayers and liposomes. Academic Press; 2010. p. 101-46.

[35] Brennan L, Owende P. Biofuels from microalgae-a review of technologies for production, processing, and extractions of biofuels and co-products. Renewable and Sustainable Energy Reviews 2010;14(2):557-77.
[36] King CW, Zarnikau J, Henshaw P. Defining a standard measure for whole system EROI combining economic "top-Down" and LCA "bottom-up" accounting. ASME ES2010. Phoenix, AZ2010.

[37] Cleveland CJ. Net energy from the extraction of oil and gas in the United States. Energy 2005;30(5):769-82.

[38] Taguchi $\mathrm{H}$, Nagao T, Watanabe $\mathrm{H}$, Onizawa $\mathrm{K}$, Matsuo $\mathrm{N}$, Tokimitsu I, et al. Energy value and digestibility of dietary oil containing mainly 1,3-diacylglycerol are similar to those of triacylglycerol. Lipids 2001;36(4):379-82. 